\title{
"Quo Vadis?" Deciphering the Code of Nongenomic Action of Thyroid Hormones in Mature Mammalian Brain
}

\author{
Pradip K. Sarkar
}

Additional information is available at the end of the chapter

http://dx.doi.org/10.5772/46206

\section{Introduction}

Thyroid hormones (TH) have major well-known actions on the growth and development of the maturing tissues including mammalian brain via activation of specific nuclear receptors leading to gene expression and subsequent target protein synthesis. Deficiency of THs has serious issues on the development on all types of tissues including brain leading to severe thyroid disorders and as a result imposes overall metabolic malfunctioning of all system organs. Endemic goiter was probably first described with cretinism by Paracelsus (1493 -1541) and by other physicians of the Alps and Central Europe. However, the relationship between cretinism and involvement of thyroid gland was lacking over centuries. Thyroid gland was literally described by Wharton in 1656. Since then the progress of research on thyroid gland gained attention particularly for its most observed pleiotypic action in number of species from aquatic animals to humans. Developments of new scientific technologies and the progress in the area of molecular biology from time to time are continually changing our concepts of the regulation of the functions of THs at the subcellular level $[1,2]$.

Immunocytochemical localization studies revealed that $\mathrm{TH}$ receptors (TR) in adult vertebrates are highly concentrated within choroids plexus, dentate gyrus, hippocampus, amygdaloid complex, pyriform cortex, granular layer of cerebellum, mammillary bodies and medial geniculate bodies. Although specific nuclear receptors for THs in adult brain have been identified, their functions are unclear about target gene expression. Imunohistochemical mapping further documented that locus coeruleus norepinephrine stimulates active conversion of L-tetraiodothyronine (L-T4) to L-triiodothyronine (L-T3). A morphologic linking between central thyronergic and noradrenergic systems has been established. This changes in TH ontogeny gradually started drawing attention that possible 
$\mathrm{TH}$ action in mature brain switches its role which may be different from its classical action mediated through nuclear receptors. As the brain approaches adulthood, nuclear levels of iodothyronines decline gradually reaching a plateau and maintain it, and the TH levels increase within nerve terminals of adult vertebrates [1]. In particular, it showed decrease in nuclear L-T3 receptor binding in adult brain compared to developing brain. These switching differences in TH ontogeny between developing and adult vertebrate brain has gradually interested investigators to search for new functional role and mechanism of action of $\mathrm{TH}$. Nevertheless, the action of THs remained limitedly judged in mature mammalian central nervous system (CNS) [3,4].

Recent research highlights about the nonconventional nongenomic action of THs and its metabolites. Adult mammalian CNS is of specific interest. Clinical observations specifically have shown that the adult-onset thyroid disorders lead to several neuropsychological diseases including but not limited to anxiety, depression, mood disorders etc. in humans. These complications can be improved with appropriate adjustment of circulatory THs [5-8]. However, the defined mechanism to explain this is inadequate. The involvement of $\mathrm{TH}$ nuclear receptors in ameliorating these neuropsychiatric dysfunctions in mature CNS is controversial. Current knowledge about the TH-responsive gene expression in adult mammalian CNS is largely unavailable except some few discrete reports with differential effects in certain brain areas. Indication of new rapid nongenomic effects of THs and its metabolites, within seconds to minutes, poses special significance.

The interest about the action of $\mathrm{TH}$ in brain originated because like the classical neurotransmitters, catecholamines, THs are also derived from the amino acid, tyrosine. Tyrosine is decarboxylased by specific aromatic amino acid decarboxylase to produce catecholamines. There are possibilities that THs can also undergo decarboxylation and form biogenic amine-like neuroactive compounds, such as thyronamines or iodothyronamines as hypothesized. However recent experiment challenges this initial hypothesis since aromatic amino acid decarboxylase failed to produce this and thus presence of $\mathrm{TH}$ specific decarboxylase is speculated [9]. For example, L-T4 and L-T3 can be decarboxylated to produce L-T4-amine and L-T3-amine respectively (Figure 1). L-T3-amine can further be deiodinated to form L-T2-amine and then further deiodination can generate L-T1-amine. Important deaminated metabolites of L-T4 and L-T3 are tetraiodothyroacetic acid (TETRAC) and triiodothyroacetic acid (TRIAC) respectively $[9,10]$. Thyronamines may have neurotransmitter-like actions. However, no evidence is present to-date to identify physiologic formation of thyronamines that describe their physiologic functions, except one new report which identified 3-iodo-thyronamine in adult brain including other tissue homogenates in sub-picomolar concentrations [10]. Few pharmacologic actions for these synthetically prepared iodothyronamines are known in other tissues. This theory of action of thyroid hormones could be like classical neurotransmission led to search for the nongenomic mechanism of action of THs.

Thus, besides the genomic concepts, a parallel idea of nongenomic of $\mathrm{TH}$ action was emerging with demonstration of direct plasma membrane- $\mathrm{TH}$ interaction and expression of some hormonal effects in a variety of cells. These studies include activation on $\mathrm{Ca}^{2+}$-ATPase 


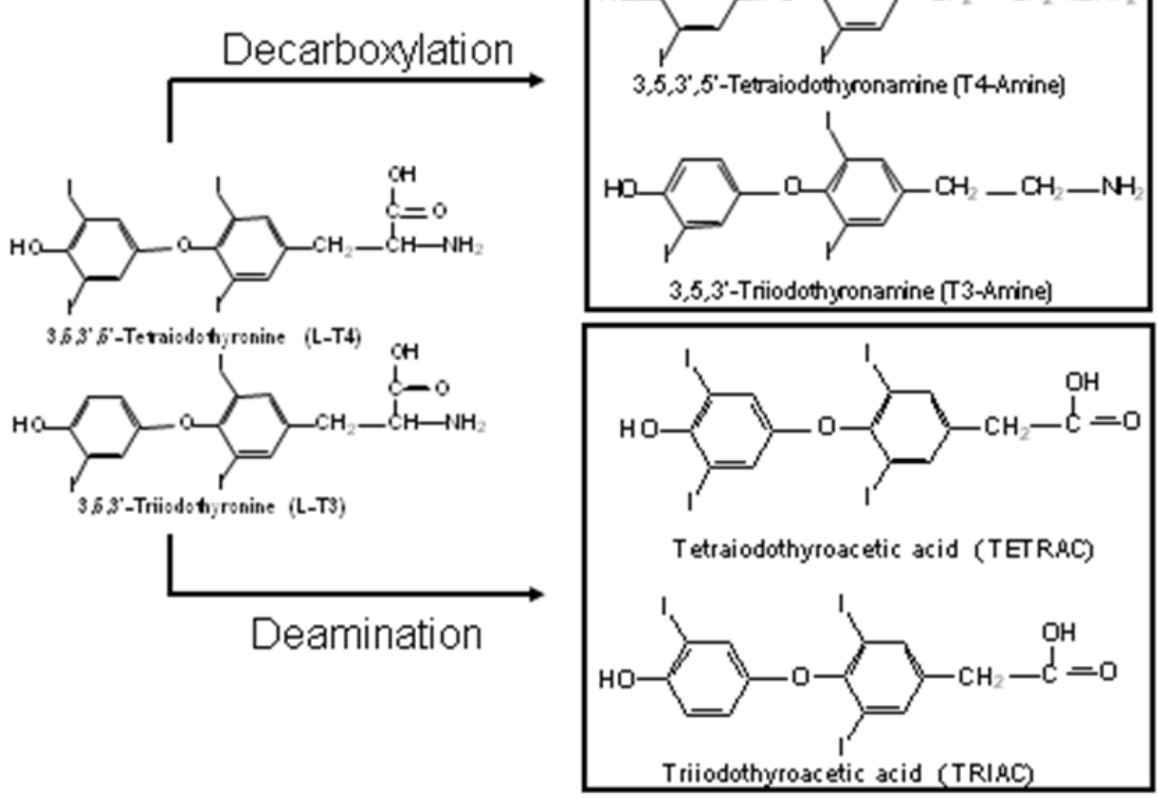

Figure 1. Thyroid hormones and their deaminated and decarboxylated products of interest.

in red blood cells, acetylcholinesterase in neuronal plasma membrane, inhibition of synaptosomal membrane $\mathrm{Na}^{+}-\mathrm{K}^{+}-\mathrm{ATPase}(\mathrm{NKA})$, rapid action of $\mathrm{L}-\mathrm{T} 3$ on synaptosomal $\mathrm{Ca}^{2+}-$ influx, identification of specific L-T3-binding sites in rat thymocyte membrane, synaptosomal membrane, depolarization of actin filaments in cultured astrocytes by $\mathrm{TH}$, and changes in second messengers and their corresponding regulatory systems following TH treatment $[1,11,12]$.

Selective uptakes of THs have also been documented within the nerve terminals. Intravenous administration of [125I]-L-T4 in rats followed by thaw mount autoradiography has described selective distribution of L-T4 in specific adult rat brain areas particularly within the nerve terminals. Within the nerve terminal this was concentrated as L-T3 [10]. Other reports about the transportation of $\mathrm{TH}$ in adult brain also indicated role of transthyretin as a major serum binding protein for $\mathrm{TH}$ required for its transportation in cerebrospinal fluids and ultimately enable crossing of $\mathrm{TH}$ of the blood brain barrier directing to the brain. A role of monocarboxylate anion transporter protein- 8 (MCT-8) also has been found to play a major role in $\mathrm{TH}$ transportation across the plasma membrane [10]. Three important enzymes called monodeiodinase are involved in TH metabolism. These are 5'-deiodinase type I (D-I), 5'-deiodinase type II (D-II) and 5'-deiodinase type III (D-III). D-I and D-II catalyzes conversion of the L-T4 to L-T3. D-I is the major deiodinating enzyme in the peripheral tissues. In brain D-II is predominantly localized in glial cells, astrocytes, and 
in the tanycytes lining the lower part of the third ventricles. D-III catalyzes the conversion of L-T3 to L-T2. Concentration of L-T3 within the nervous system has been attributed to the brain D-II which has major functions in regulating the overall neuronal homeostasis for TH. Expression of D-II in nervous tissue is implicated in the neuronal uptake of the circulatory L-T4 and its conversion to L-T3 followed by its supply to the neuronal targets. Expression of D-II is an important protective mechanism against hypothyroidism. This prevalence of TH homeostasis is a preventive measure and thought to be neuroprotective [1,13-16].

Interest also materializes to explore further the nongenomic mechanism of action of THs in adult mammalian CNS. In this context TH-mediated signal transduction pathways are also being investigated. Particularly the regulation of the activation of the second messenger systems and subsequent protein phosphorylation are of much awareness. Understanding of the mechanism of action of TH in adult mammalian brain has key implications in the higher mental functions, learning and memory, and in the regulation of several neuropsychiatric disorders developed during adult-onset thyroid dysfunctions in humans.

\section{Aim of the article}

The major goal of this article is to search, discuss and review the nongenomic rapid actions of THs in mature mammalian CNS. This article aims to begin with observations describing subcellular distribution, and concentrations of THs within the brain and its biochemical and physiologic consequences, specific binding of THs onto the neuronal plasma membrane to examine for specific plasma membrane receptors of THs and correlate the receptor-binding followed by a specific cellular function. Next, the molecular basis of the TH and plasma membrane receptor interaction-mediated signals are evaluated via possible activation of Gprotein signaling pathway, second messenger systems, and subsequent target protein phosphorylation.

\section{Hypothesis}

Thyroid hormones exercise a nongenomic action on the adult mammalian brain possibly by binding to neuronal membrane receptors followed by activation of second messenger cascade systems leading to substrate level protein phosphorylation and dephosphorylation by protein kinases and protein phosphatases (Figure 2).

\section{Experimental tissue of interest}

Author's experiments and results reported in this manuscript are obtained from the purified synaptosomes prepared from young adult rat brain cerebral cortex. Synaptosomes are subcellular nucleus-free preparation purified through density gradient centrifugation [17]. The question may arise why synaptosome? Synapses are the ultimate routes of communications in neurons where electrical impulses are normally translated to chemical signals from one neuron to the other leading to subsequent biochemical and physiologic events. This preparation is a fragment of neurons containing the neuronal membrane, 


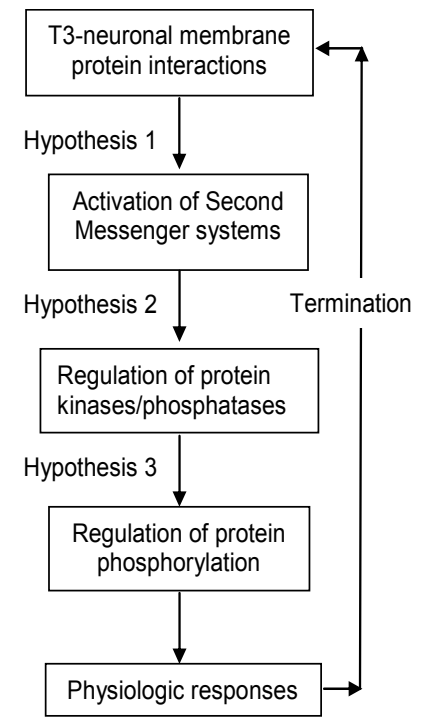

Figure 2. Hypothesis: Proposed nongenomic action of thyroid hormones in adult mammalian brain.

(a)
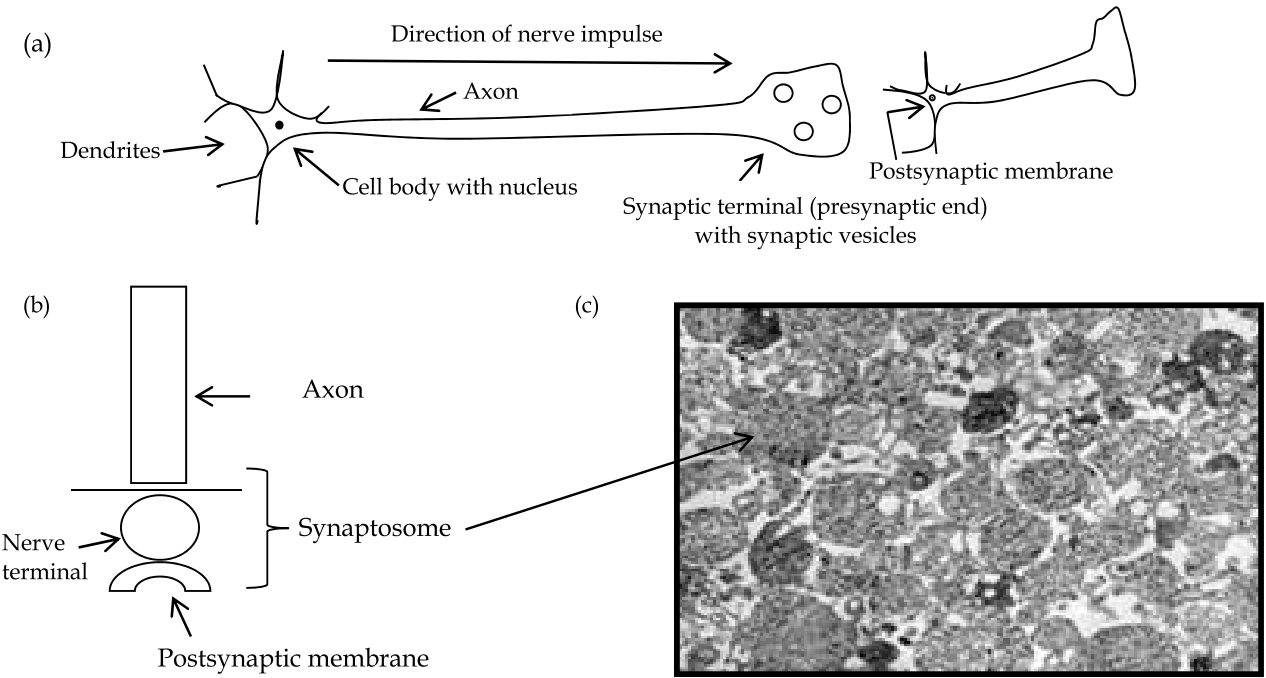

Figure 3. (a) A typical neuron. (b) Cartoon of a neuron showing synaptosome. (c) Scanning electron microscopic image of synaptosome.

Synaptic vesicles, and the other intracellular components (Figure 3). Synaptosomes can be considered as isolated nerve terminals. Synaptosomes are obtained after homogenization and fractionation of nerve tissue. The fractionation step involves several centrifugations steps to separate various organelles from the synaptosomes. Synaptosomes are formed from the phospholipid layer of the cell membrane and synaptic proteins such as receptors. 
Synaptosomes are frequently used to study synaptic signal transduction pathways because they contain almost the entire molecular machinery necessary known for the uptake, storage, release of neurotransmitters, receptor properties, and enzyme actions etc.

\section{Subcellular levels of L-triiodothyronine (L-T3) and L-thyroxine (L-T4) in adult rat brain cerebral cortex}

As the brain approaches adulthood, nuclear iodothyronine concentrations gradually decreases reaching a plateau and maintains it, and the $\mathrm{TH}$ levels increase within nerve terminals of adult vertebrates [1,18-21]. It also demonstrated decrease in L-T3-binding in adult brain compared to developing brain.

Although, evidence of transportation ${ }^{125} \mathrm{I}-\mathrm{L}-\mathrm{T} 3$ and ${ }^{125} \mathrm{I}-\mathrm{L}-\mathrm{T} 4$ within the nerve terminal was demonstrated following intravenous injection in adult rat brain $[10,18,19,22]$, its euthyroid concentrations and subcellular distribution was never been evaluated until recently [13,23]. Intravenous administration of $\left[{ }^{125} \mathrm{I}\right]-\mathrm{L}-\mathrm{T} 4$ in rats followed by thaw mount autoradiography showed distribution of L-T4 in selective areas of adult brain in a saturable manner. Gradually L-T4 was concentrated more within nerve terminals fractions, where L-T4 was monodeiodinated to produce L-T3, the active form of TH [10]. L-T4 and L-T3 transportation within neurons are shown to occur by two different mechanisms. L-T3 is actively taken up in a saturable manner, while L-T4 transportation occurs by diffusion and in a non-saturable way. L-T4-transporation within the neuron is dependent upon L-T4-concentration gradient between extracellular and intracellular compartments and is maintained by high deiodination rate of L-T4 to L-T3 [24]. Role of transthyretin has also been described as a major binding protein in cerebrospinal fluid. Transthyretin has been implicated to facilitate L-T4 transportation across the blood-brain-barrier and finally into the brain. Recently MCT8 has been ascribed to be the most effective TH transporter [25]. These MCT- 8 are 12 transmembrane spanning proteins, and in particular plays a major role for very specific transportation of L-T3 within the neurons followed by the active conversion of the prohormone L-T4 to L-T3 by the D-II within the CNS [26]. D-II is essentially important for the conversion of the prohormone L-T4 into the active L-T3 within the CNS. However, understandings of the levels of THs within the neurons are imperative. This information is crucial to explore the role of L-T3 in neural signal transmission in mature brain. To help meet this requirement the following study was performed to quantify and compare the levels of THs in adult rat brain cerebral cortex.

\subsection{Comparison of the levels of L-tetraiodothyronine (L-T4) and L- triiodothyronine (L-T3) in subcellular fractions}

While serm levels of L-T4 $(\sim 41 \mathrm{ng} / \mathrm{ml})$ and L-T3 $(\sim 0.7 \mathrm{ng} / \mathrm{ml})$ were found consistent with the normal peripheral results, this assay system could not detect L-T4 in either synaptosomal or non-synaptic mitochondrial fractions. However, the L-T3 levels in synaptosomes $(0.45 \pm 0.06$ $\mathrm{ng} / \mathrm{mg}$ synaptosomal protein), and non-synaptic mitochondria (1.44 $\pm 0.12 \mathrm{ng} / \mathrm{mg}$ 
mitochondrial protein) were significant. The levels of L-T3 in non-synaptic mitochondria were $\sim 3.2$-fold higher compared to synaptosomal values in cerebral cortices $[13,16]$. The finding of undetectable levels of synaptosomal L-T4 was consistent with other studies $[14,27,28]$. A higher fractional rate of D-II activity that converts L-T4 to L-T3 is attributed $[29,30]$.

This study quantifies the TH concentrations from adult rat brain synaptosomal and nonsynaptic mitochondria. Although L-T4 levels could not be detected in synaptosomal and nonsynaptic mitochondrial fractions, fair amounts of L-T3 were detected in these fractions purified from adult rat brain cerebral cortex $[13,16]$. Undetectable levels of synaptosomal L-T4 levels were also supported within synaptosomal fractions obtained from adult rat brain [27].

Despite very low levels of TH in hypothyroid condition as determined by serum levels of $\mathrm{TH}$, previous report has shown that L-T3 production in brain is pretty high in stress situations like hypothyroidism [13]. D-II has also been shown to be activated in other stressful conditions and indicated to have a protective role in stressed brain [31]. Stimulated levels of D-II have been described during hypothyroidism. This supports the first initial report [13] of elevation of brain L-T3 levels during n-propylthiouracil (PTU)-induced hypothyroid conditions [14,15,32]. In brain, approximately $80 \%$ of the L-T3 is produced locally from L-T4 by D-II. The fractional rate of conversion of L-T4 to L-T3 is remarkably high in brain [29]. This might be a possible reason for undetectable L-T4 levels due to rapid conversion of L-T4 to L-T3 in these fractions. To detect the endogenous TH levels the subcellular fractions were ruptured hypo-osmotically. The use of 8-anilinonaphtho-sulfonic acid in the radioimmunoassay medium excluded the possibility of the non-detectable protein bound form of the hormone by releasing the endogenously bound form of the hormones [13].

Comparatively higher levels of L-T3 in the mitochondria may have implications on the mitochondrial bioenergetics such as, cellular oxygen consumption, oxidative phosphorylation and ATP synthesis, mitochondrial gene expression. These are few of the major regulatory functions of $\mathrm{TH}$. THs also have been shown to affect mitochondrial genome mediated through imported isoforms of nuclear TH receptors and influence various mitochondrial transcription factors [3,33]. Concentration and localization of radiolabeled LT3 within the nerve terminal was the first landmark research described in adult rat brain. This further followed with the immunohistochemical mapping demonstrating locus ceruleus norepinephrine stimulating active conversion of L-T4 to L-T3. This established a morphologic co-localization of central thyronergic and noradrenergic systems. Overall TH levels within different compartment of brain may have discrete, differential and potential regulatory function for neurotransmission in adult mammalian brain [10].

\subsubsection{Thyroid hormone levels in hypothyroid rat cerebrocortical synaptosomes}

Synaptosomal levels of L-T3 were also studied in different thyroidal conditions. Serum levels of L-T3 and L-T4 confirmed establishment of peripheral hypothyroidism induced by 14 days of intra-peritoneal (i. p.) injections of PTU (2 mg/g BW). However, surprisingly hypothyroid rat brain showed $\sim 9.5$-fold higher amount of L-T3 (126 nM) in synaptosomes 
compared to euthyroid control values. A single i. p. injection of L-T3 (2 $\mu \mathrm{g} / \mathrm{g} \mathrm{BW})$ to the hypothyroid rats decreased the synaptosomal levels of L-T3 by $~ 1.6$-fold compared to the hypothyroid rats and was still $\sim 6$-fold higher than the euthyroid value. An increase in $~ 2.5-$ fold of the L-T3 levels was noticed in euthyroid plus L-T3 (2 $\mu \mathrm{g} / \mathrm{g} \mathrm{BW})$ group (Figure 4) [13]. Although the levels of L-T3 in whole rat brain homogenate was found to be in low nanomolar ranges [22], two concurrent reports estimated synaptosomal levels of L-T3 to be $\sim 14.6 \mathrm{nM}$ [23], and $13 \mathrm{nM}$ [13] in adult rat brain synaptosomes. Observation of high levels of synaptosomal L-T3 were also supportive [15] in hypothyroid rat cerebral cortex by $~ 1.7-$ fold compared to the control values maximally at day 4 of induction of hypothyroidism while the serum levels of L-T3 remained at the hypothyroid levels.

Hypothyroid condition shows an appreciable decline in both serum L-T4 and L-T3 level in rats in a usual way as found by other investigators [34]. Although it has been shown earlier that in hypothyroid condition, the whole brain, or different regions of the brain, maintain similar levels of L-T3 compared to the euthyroid control rats through increased activity of D-II, and corresponding high fractional rate of L-T4 to L-T3 conversion [35,36], insufficient evidence is available except for a few recent reports to quantitate the synaptosomal concentration of thyroid hormones. Approximately 8-fold higher concentration of L-T3 has been found in synaptosome compared to the whole brain in euthyroid rats. Our observation of approximately 9.5-fold higher L-T3 content in synaptosome of hypothyroid rats compared to the euthyroid controls may be the result of a higher fractional rate of L-T3 production by increased activity of D-II, and a correspondingly higher selective uptake and concentration of L-T3 molecules in the synaptosomes to cope up with the physiological need of THs in this tissue at this condition $[13,23,37,38]$.

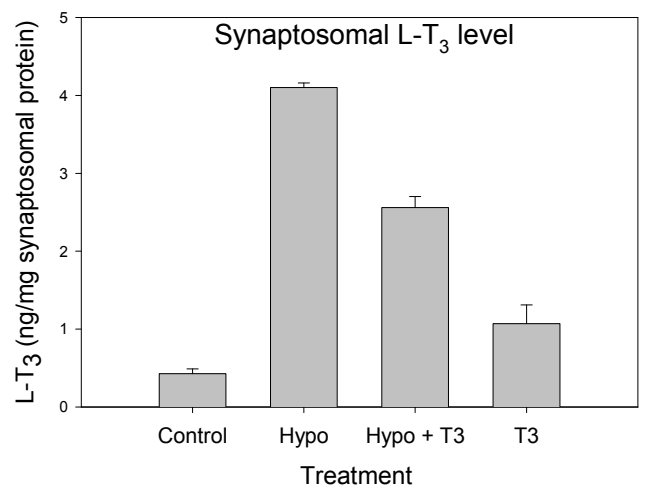

Figure 4. L-T3 levels in rat cerebrocortical synaptosomes in various thyroid states. (Ref. Sarkar and Ray 1994, Neuropsychopharmacology 11: 151-155 acknowledged [13]).

In euthyroid rat brain, selective uptake of ${ }^{125} \mathrm{I}-\mathrm{L}-\mathrm{T} 3$ and its concentration in synaptosomal compartment have been demonstrated [10]. In addition, the use of hypothyroid animals only after 14 days of PTU treatment, where some adaptive mechanisms still unknown in nature prevail, do not reach the equilibrium as compared to the animals kept in chronic 
hypothyroid condition for a much longer duration as used by other workers. This may be one of the reasons for maintaining a high level of synaptosomal L-T3 in our hypothyroid rats. Expression of the data in different forms such as per gram organ (brain) basis, or per mg compartmental (synaptosomal) protein basis, as presented in our experiment, also becomes an additive factor for discrepancies among different groups of workers regarding the quantitative aspects of L-T3 or L-T4 in the brain [23,34,38,39]. The fall in L-T3 concentration in synaptosomes prepared from L-T3-treated hypothyroid rat cerebral cortex may be the result of inhibition of D-II activity after 24 hours of the L-T3 administration, in the presence of the considerable amount of exogenous L-T3. An inhibition in the activity of D-II has been noticed within 4 hours of L-T3 treatment to the thyroidectomized rats. A rise in the synaptosomal L-T3 level in the hypothyroid rats, and a fall in the same in the L-T3treated hypothyroid animals after 24 hours of L-T3-treatment, also reflects the tendency for a compensatory regulatory mechanism of thyroid hormone metabolism in the adult rat brain in altered thyroid conditions, although the nature of the mechanism remains unknown. L-T3-treated control rats have shown higher levels of synaptosomal L-T3, compared to the control values. This may be a result of the extra L-T3 transport influenced by a high dose of exogenously administered L-T3 $(2 \mu \mathrm{g} / \mathrm{g})[18,19,24]$.

Observation of undetected levels of L-T4 within cerebrocortical synaptosomes may reflect a state of rapid conversion of L-T4 to L-T3 in the brain by D-II enzyme. Other researchers have already shown that after intravenous administration of radiolabeled L-T4 and L-T3, the hormone is concentrated as L-T3 in a synaptosomal fraction of the whole rat brain, and L-T4 to L-T3 conversion occurs very rapidly within the nerve cells. L-T3 formed in the neuronal cell body then may be translocated down the axon to the synaptic ends. Saturable and nonsaturable uptake of L-T3 and L-T4 in isolated synaptosomes in an in vitro model also indicated two-component L-T3-uptake system [18,19,24,37,38].

The prediction of a role of D-II as suggested [13] is further supported by few other studies $[15,31]$. Increased D-II activity is suggested in hypothyroid brain. This is attributed to the maintenance of normal brain concentrations of L-T3 even under low peripheral levels of LT4 [31]. The high level of L-T3 as observed by us is supported and suggested for maintenance of brain homeostasis. This demonstrated onset of a central homeostasis for THs in adult hypothyroid brain between the $1^{\text {st }}$ and $2^{\text {nd }}$ day, its maintenance for about 16-18 days and thereafter declined between the $18-20^{\text {th }}$ day [15]. This report also confirms and confers higher activity of D-II ( 1.6-fold higher compared to control) within the cerebrocortical synaptosomal fraction during short-term brain-hypothyroidsm. It is described as a protective mechanism of brain by raising the brain L-T3 levels. Another study also documents an increase in D-II activity within various brain regions and decrease in D-III activity, except in cerebrellum and medulla where specific D-III activity remained undetected [40]. However, controversially, although these investigation did observe higher D-II activity within various areas of adult brain during hypothyroidism, the changes in L-T3 levels remained lower than normal values as was noticed in case of serum levels of hypothyroidism. This investigation could not explain this high D-II activity and lower L-T3 levels in brain regions. The levels of THs measured in this study also were shown to be 
lower than found by other investigators. Some assay in brain regions was also performed in tissue homogenates instead of particular subcellular fractions. Possibly differences in the concentrations of THs could be due to a different method of severe extraction procedure employed to extract brain tissue THs resulting in loss of it.

The data emerged from our study reveal the quantitative aspects of involvement of L-T3 in synaptosomes in different thyroid states, and favors its role in neuronal functions as formerly described [10,41]. A stimulation of synthesis of synapsin-1 protein (related to neurotransmission) by L-T3 in the developing brain has been reported [42]. Although, the synaptosomal L-T3 levels varied widely with different treatments, our result illustrates a unique, but unknown regulatory mechanism of the $\mathrm{TH}$ metabolism in the mature mammalian brain.

\subsection{Modulation of neuronal plasma membrane $\mathrm{Na}^{+}-\mathrm{K}^{+}-\mathrm{ATPase}$ specific activity as a function of specific binding of L-triiodothyronine in adult rat brain cerebrocortical synaptosomes}

Subsequently the idea of concentration, distribution and metabolism of THs within the mature brain generated interest to search for potential role of $\mathrm{TH}$ and its nongenomic interaction, if any, with neuronal plasma membrane. TH is well known for its regulation of energy metabolism in developing tissues including brain. However, adult brain has not shown this effect on energy metabolism under the influence of $\mathrm{TH}$ until recently. Maintenance of ionic gradients by plasma membrane $\mathrm{Na}^{+}-\mathrm{K}^{+}$-ATPase (NKA) is one of the important cellular events by which $\mathrm{TH}$ regulate energy metabolism. NKA is an ion pump responsible for maintaining $\mathrm{Na}^{+}$and $\mathrm{K}^{+}$ion gradients across the cellular plasma membrane in eukaryotic cells. The $\mathrm{Na}^{+}$and $\mathrm{K}^{+}$ion gradients are important for establishment of resting membrane potentials as well as for transport of certain molecules. NKA has special significance in maintaining membrane potentials in neurons. Inhibition of NKA has been shown to release acetylcholine [43] and norepinephrine [44] from rat cortical synaptosomes, presumably as a result of depolarizing effects of lowered $\mathrm{K}^{+}$gradients. The level of NKA activity could therefore have consequence for the regulation of the neurotransmitter release and uptake across the synaptic membrane [43].

\subsubsection{In vivo and in vitro actions of $L-T 3$ on synaptosomal $\mathrm{Na}^{+}-\mathrm{K}^{+}$-ATPase activity}

A dose-dependent inhibition of synaptosomal NKA activity by L-T3 both in in vivo [45], and in in vitro [46] conditions have been shown. This may be related to the differences in L-T3 status in adult rat cerebrocortical synaptosomes. L-T3 administration in a single i.p. injection showed inhibition of synaptosomal NKA specific activity maximally at 24 hours postinjection by $\sim 44 \%$ compared to respective control euthyroid values. A range of L-T3 concentration ( 0.1 to $4.0 \mu \mathrm{g} / \mathrm{g} \mathrm{BW}$, single i. p. injection) administered in vivo showed dosedependent inhibition of the synaptosomal NKA activity. In contrast PTU-treated hypothyroid animals showed $~ 38 \%$ increase in the NKA activity compared to the control values. This increase in NKA activity was abolished by injection of a single L-T3 injection 
$(2 \mu \mathrm{g} / \mathrm{g} \mathrm{BW})$ to almost close to the euthyroid levels. However, this study could not distinguish between the genomic and nongenomic effects of L-T3. TH has also been reported to influence $\mathrm{K}^{+}$-evoked release of $\left[{ }^{3} \mathrm{H}\right]-\mathrm{GABA}$ in adult rat cerebrocortical synaptosomes. Such evidence indicates a possible role of $\mathrm{TH}$ in neurotransmission in adult mammalian brain. A functional correlation between L-T3 binding and the corresponding inhibition of NKA activity under in vitro conditions in the synaptosomes of adult rat cerebral cortex were established [46]. To further test the hypothesis of nongenomic action of TH we investigated NKA activity in isolated synaptosomes which is devoid of nucleus to avoid the chances of nuclear activation [46]. In fact, in vitro addition of L-T3 (1x10-12 $\mathrm{M}$ to $10 \times 10^{-8} \mathrm{M}$ ) within 10 minutes of incubation indicated a dose-dependent inhibitory response to NKA activity. Such immediate action of L-T3 added in in vitro in synaptosomes was concluded as rapid nongenomic action of L-T3 on synaptosomal membrane NKA [46]. Further inhibition of NKA activity was corroborated with gradual binding of [125I]-L-T3 to specific L-T3-binding sites in synaptosomes. Thus a physiologic response tied to the specific L-T3-binding in the synaptosomal membrane was demonstrated.

The presence of high affinity low capacity nuclear $\mathrm{TH}$ receptors in adult rat brain has been reported. Further evidence shows selective uptake of [ $\left.{ }^{125} \mathrm{I}\right]-\mathrm{L}-\mathrm{T} 3$ and rapid conversion of LT4 to L-T3 in synaptosomal fraction of adult rat brain. Specific [ $\left.{ }^{125} \mathrm{I}\right]-\mathrm{L}-\mathrm{T} 3$ binding sites have also been demonstrated in the synaptosomes of adult rat brain [47] and chick embryo [48]. However, no functional relationship could be established due to the interaction of $\mathrm{TH}$ and its membrane receptor so far in adult brain.

Scatchard plot analysis demonstrated two sets of specific L-T3 binding sites: one with high affinity (Kd1: $12 \mathrm{pM}$; $B_{\max 1:} 3.73 \pm 0.07$ fmols $/ \mathrm{mg}$ protein), and the other with low affinity ( $\mathrm{K}_{\mathrm{d} 2}$ : $1.4 \pm 0.05 \mathrm{nM}$; $B_{\max 2:} 349 \pm 7$ fmols/mg protein). $\mathrm{K}_{\mathrm{d}}$ represents dissociation constant. Bmax represents maximum binding capacity. Rationale between gradual L-T3 binding and the corresponding dose-dependent L-T3-induced inhibition of synaptosomal NKA was established in vitro [46].

The relative order of potencies of binding affinities for the synaptosomal L-T3 binding sites and relative inhibition of NKA activity in the presence of different L-T3 analogues were as follows: L-T3>L-T3-amine $>$ L-T4=L-TRIAC $>$-T3 $>$ L-T2, and L-T3 $>$ L-T3-amine $>$ L-T4 $>$ LTRIAC $>$ r-T3 $>$ L-T2, respectively. The concentrations of $\mathrm{TH}$ analogues required to displace $50 \%$ specific binding (ED50 value) of ${ }^{125}$ I-L-T3 to its synaptosomal binding sites were 10-, 63-, 63-, 1000- and $6250 \mathrm{nM}$, respectively. This study showed the nature of inhibition of synaptosomal NKA activity as a function of L-T3 occupancy of synaptosomal receptor sites in mature rat brain [46].

This investigation demonstrates a novel action of $\mathrm{TH}$ in mature rat brain. This is the first report presenting a relationship between the inhibitions of synaptosomal NKA as a functional effect of L-T3 binding to its synaptosomal receptor in the cerebral cortex of adult rat. Occupancy of specific high affinity L-T3 binding sites demonstrated a concentrationdependent inhibition of the NKA activity with a maximum of $59 \%$. At $1 \times 10^{-10} \mathrm{M}$ L-T3 concentration the enzyme inhibition was $\sim 35 \%$ and the saturation of the L-T3 binding sites 
was $\sim 74 \%$. This appears to be physiological. Further inhibition of NKA activity as found with higher concentrations of L-T3 $\left(5 \times 10^{-10}-1 \times 10^{-7} \mathrm{M}\right)$, corresponds to the increase in the occupancy of the L-T3 binding sites (maximum of $\sim 80 \%$ ) at the low affinity binding range. However, this site was not saturated by $15.4 \mu \mathrm{M}$ L-T3 used for determining non-specific binding. Hence, it is possible that this low affinity binding is due to non-specific effects of several other proteins located in synaptosomes. The relationship between the binding of LT3 to its synaptosomal binding sites and the concentration dependent inhibition of the enzyme activity appears to hold good only with the occupancy of high affinity sites up to $5 \mathrm{x}$ $10^{-10} \mathrm{M}$ L-T3 [46]. Synaptosomes prepared from chick embryo cortex were also reported to have two sets of L-T3 binding sites [48]. Their properties and ontogeny showed a marked difference from those of nuclear receptors. Even though NKA activity was suppressed beyond the saturating concentration of L-T3 at high affinity binding sites, this may be nonspecific and non-physiological. The relative order of binding affinities for $\mathrm{TH}$ analogues to the L-T3 binding sites and the inhibitory potencies for NKA activity were also correlated in the synaptosomes. L-T3-amine was used to examine its potency to inhibit specific [ $\left.{ }^{125} \mathrm{I}\right]-\mathrm{L}-\mathrm{T} 3$ binding in synaptosomes with the idea that it may be a decarboxylated product of L-T3 and may have actions like L-T3. The ED50 value for L-T3-amine was determined as $10 \mathrm{nM}$. At this dose, L-T3-amine also inhibited the synaptosomal NKA activity by $\sim 51 \%$ compared with LT3. This result is also in good agreement with earlier studies, in which L-T3-amine was shown to be $\sim 71 \%$ as effective as L-T3 in stimulating $\mathrm{Ca}^{2+}$-ATPase activity at a dose of $10 \mathrm{nM}$ in human RBC [49]. In earlier studies, L-T3-induced increase in NKA activity in the developing brain [50] and kidney cortex [51] of rat was reported to be due to an increase in the mRNA levels of $\alpha, \alpha+$ and $\beta$-subunits of the enzyme, while the NKA in adult was not responsive to L-T3. However, a dose-dependent inhibition and regulation of synaptosomal NKA activity in different in vivo situations was noticed. The immediate effect of added L-T3 on the synaptosomes appears to be nongenomic as synaptosomes do not have nuclei. This may exclude the possibility of involvement of nuclear receptors as reported earlier by us. One possible effect of L-T3 may be mediated through membrane receptors. Recently, membrane binding proteins for iodothyronines has been described in plasma membranes of most cells [52]. This protein has been designated as an integrin $\alpha \mathrm{V} \beta 3$. Also a role of MCT-8, a membrane spanning protein, has been ascribed as a very active and specific transporter of THs and some of its metabolites across the membrane [25,53]. However, its action through cytoplasmic L-T3-responsive proteins cannot be ruled out.

In conclusion this study demonstrates, for the first time, a correlation between the binding of $\mathrm{TH}$ to its putative receptors and inhibition of NKA activity in the synaptosomes of adult rat brain [46]. This may have implications in the involvement of thyroid hormone on important mental functions in adult mammalian brain.

\subsection{In search for possible second messenger mediated events in synaptosomal L- T3-induced signaling}

The evidence of L-T3-synaptosomal membrane interaction in association with the inhibition of the synaptosomal membrane NKA activity led us to search for if the L-T3-induced action 
is mediated via activation or regulation of the second messenger cascade systems. Besides the cyclic nucleotide cyclase systems calcium $\left(\mathrm{Ca}^{2+}\right)$ also plays an important role in cellular signal transmission. $\mathrm{Ca}^{2+}$-influx is a major event in neurotransmission. Keeping such visions we further intended to explore the role of $\mathrm{Ca}^{2+}$ in L-T3-induction.

\subsubsection{Effect of L-T3 on synaptosomal Ca+2+influx: A comparison between euthyroid and hypothyroid brain}

Metabotropic events are often initiated at the membrane level, mediated and amplified through G-protein coupled receptors (GPCR) and/or ion channels followed by activation of second messenger system and subsequent substrate protein phosphorylation. $\mathrm{Ca}^{2+}$-influx is an important physiological function in brain, following which cascades of membrane events occur finally leading to neurosignaling. Disruption in this crucial membrane phenomenon may lead to variety of $\mathrm{Ca}^{2+}$-dependent neuropsychological disorders. Although $\mathrm{TH}-$ mediated $\mathrm{Ca}^{2+}$ entry in adult rat brain synaptosomes [54,55], and in hypothyroid mouse cerebral cortex [56] have been reported, it's synaptic functions in adult neurons in dysthyroidism is unclear. Keeping in mind the role of $\mathrm{Ca}^{2+}$ ions as a messenger in the signaling pathway the effect of L-T3 on intracellular $\mathrm{Ca}^{2+}$-influx, in vitro, was studied.

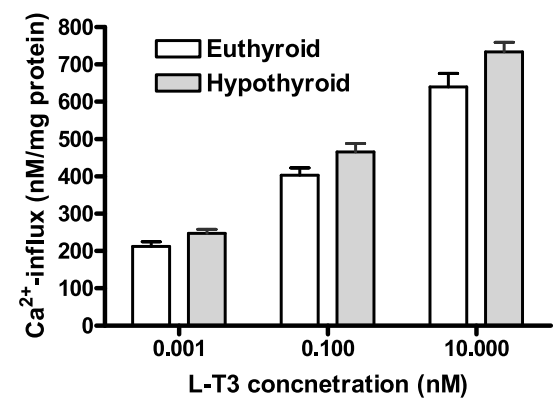

Figure 5. Effect of L-T3 on intrasynaptosomal $\mathrm{Ca}^{2+}$-concentration in euthyroid and PTU-induced hypothyroid rat cerebral cortex in vitro (Ref. Modified from Sarkar and Ray 2003, Hormone and Metabolic Research 35: 562-564 acknowledged [57])).

Our study demonstrates a regulation and homeostatic mechanism of $\mathrm{Ca}^{2+}$ accumulation within cerebrocortical synaptosomes of hypothyroid adult rat [57]. Application of brain physiologic concentrations of L-T3 $(0.001 \mathrm{nM}$ to $10 \mathrm{nM})$, in vitro, significantly triggered $\mathrm{Ca}^{2+}$ sequestration both in the euthyroid and hypothyroid rat brain synaptosomes in a dosedependent manner (Figure 5). Unexpectedly, PTU-induced hypothyroid synaptosomes showed significant levels of increase in $\mathrm{Ca}^{2+}$-influx compared to euthyroid controls between $0.1 \mathrm{nM}$ and $10 \mathrm{nM}$ doses of L-T3. However, $0.001 \mathrm{nM}$ dose of L-T3 did not show significant changes between euthyroid and hypothyroid values.

Present study validates the role of $\mathrm{Ca}^{2+}$ ions under the influence of L-T3 in the synaptosomes from adult rat brain cerebral cortex. L-T3-induced dose-dependent $\mathrm{Ca}^{2+}$-entry both in euthyroid and PTU-induced hypothyroid rat brain synaptosomes at low L-T3 doses $(0.001$ 
$\mathrm{nM}$ to $10 \mathrm{nM}$ ). This evidence indicates role of $\mathrm{Ca}^{2+}$ as a second messenger in synaptic functions. L-T3 also has been documented to increase ${ }^{45} \mathrm{Ca}$ uptake and $\mathrm{Ca}^{2+}$-influx in adult euthyroid rat synaptosomes, and in hypothyroid mouse cortex. An enhancement of nitric oxide synthase (NOS) activity in adult rat cerebrocortical synaptosomes was shown [55]. This present study demonstrated a significant increase in $\mathrm{Ca}^{2+}$ accumulation in hypothyroid rat brain cerebrocortical synaptosomes compared to euthyroid control at below $(0.1 \mathrm{nM})$ and at about brain physiologic concentrations $(10 \mathrm{nM})$ of L-T3. At present clear understanding for the L-T3-induced release of intracellular calcium is not known; however possibility for LT3-induced action in neuronal cells cannot be left out. Use of sodium azide blocked any mitochondrial accumulation of calcium. Our earlier studies have shown that $10 \mathrm{nM}$ and 100 $\mathrm{nM}$ dose of L-T3 could saturate the specific synaptosomal L-T3-binding sites by $\sim 69 \%$ and $\sim 74 \%$ respectively. L-T3-mediated physiological increase in synaptosomal $\mathrm{Ca}^{2+}$ accumulation could be attributed to receptor-mediated physiological response having its maximal effect at $10 \mathrm{nM}$ dose of L-T3. The differences in the observation of increased rate of $\mathrm{Ca}^{2+}$ accumulation in hypothyroid synaptosomes compared to the euthyroid values reflected an adaptive mechanism. This could be credited to homeostatic mechanism to overcome PTUinduced stress conditions persisted in the adult neuron. High intrasynaptosomal L-T3 level ( $~ 9.5$-fold higher; $2.56 \mathrm{ng} / \mathrm{mg}$ synaptosomal protein $\cong 126 \mathrm{nM} \mathrm{L-T3}$ ) could be one of the reasons. Although hypothyroid condition showed an appreciable decrease in both serum levels of L-T4 and L-T3 as predicted, supportive studies showed maintenance of similar levels of brain L-T3 in hypothyroid conditions through increased activity of D-II suggesting high fractional rate of L-T4 to L-T3 conversion. In brain approximately $~ 80 \%$ of L-T3 is produced locally from L-T4 by D-II. This data supports thyroid hormone-Ca ${ }^{2+}$-ion interaction for normal functioning of adult brain during different neuropsychological conditions.

The important functional role of $\mathrm{Ca}^{2+}$ and several calcium-dependent proteins in neuronal signal transduction are well recognized. $\mathrm{Ca}^{2+}$ has been shown to inhibit neuronal NKA activity. $\mathrm{Ca}^{2+}$-influx also lead to $\mathrm{Ca}^{2+}$-dependent activation of protein kinase $\mathrm{C}$ and/or $\mathrm{Ca}^{2+} / \mathrm{CaM}$-dependent protein kinases followed by direct or indirect activation of phosphorylation of several target proteins. This indicated a rapid nongenomic action of LT3.

\subsubsection{Is thyroid hormone-membrane interaction is linked to G-protein coupled receptors (GPCR)?}

\subsubsection{Association of $G$ proteins with membrane receptors}

G proteins are GTP-binding proteins that couple activation of seven-helix receptors by neurotransmitters at the cell surface for the activation of the effector enzymes-adenylate cyclase (AC) or guanylate cyclase (GC), which synthesize the corresponding cyclic nucleotides, cAMP or cGMP respectively and regulate protein kinases., such as protein kinase A (PKA), protein kinase C (PKC) etc. Metabotropic events are often initiated at the membrane level, mediated and amplified through GPCR followed by activation of second 
messenger system and subsequent substrate protein phosphorylation. Phospholipase C (PLC), another effector enzyme, generates inositol triphosphate (IP3) and diacylglycerol (DAG), the latter of which releases intracellular stores of calcium. The cAMP, cGMP, $\mathrm{Ca}^{2+}$, DAG and $\mathrm{IP}_{3}$ act as second messengers and activate protein kinases with broad substrate specificity. The kinases phosphorylate key intracellular proteins, including ion channels, enzymes, and transcription factors which modulate cellular biological processes [58,59]. Guanine nucleotides are known to have dual effects on most hormone-sensitive AC systems. This modulates activation of $\mathrm{AC}$ and binding of hormone to receptor. In neuronal membranes guanylate nucleotides has been shown to be required for the stimulation of AC. However, no modulation of TH binding at appropriate guanylate nucleotide concentrations has been reported. It is well established that cholera toxin enhances the activity of $\mathrm{Gs}_{\alpha}$ (stimulatory $\mathrm{G}$ protein $\alpha$-subunit) by ADP-ribosylating $\mathrm{Gs}_{\alpha}$ subunit and inhibiting GTPase activity associated with the protein. This increases cAMP production.

The activity of NKA is regulated by various catecholamines $[45,46,60]$ as well as by L-T3 $[45,46]$. Inhibition of NKA has been demonstrated in intact cell preparations by phorbol esters, dibutyryl cAMP, and phospho-DRPP-32 (dopamine- and cAMP-regulated phosphoprotein of molecular weight $32 \mathrm{kD}$ ), a protein phosphatase inhibitor [61-63].

Some information focuses to effect of $\mathrm{TH}$ or its metabolites on noradrenergic like responses. This idea develops since $\mathrm{TH}$ has possibility to produce a family of biogenic amine-like neurotransmitter compounds catalyzed by aromatic amino acid decarboxylase, such as iodothyronamines. Physiologic identification of these family of TH-derived iodothyronamines have not yet been discovered until recently in rat brain and in rat and human blood. These two compounds are monoiodothyronamine and thyronamine [10]. Thinking this could be a possibility before this identification of monoiodothyronamine and thyronamine were reported we studied the effect of L-T3 on synaptosomal NKA activity using various $\beta$ - and $\alpha$-adrenergic agonists and antagonists known to regulate $G_{s}$ and $G_{i}$ proteins of the neuronal signal transduction system, in vitro.

Our studies showed that although both L-T3 and isoproterenol ( $\beta$-adrenergic receptor [ADR] agonist and activator of Gs-protein) similarly inhibited synaptosomal NKA activity, propranolol ( $\beta$-ADR antagonist) could only block the effect of isoproterenol, but not the effect of L-T3. Instead propranolol produced a dose-dependent potentiation of the inhibitory influence of L-T3 (Figure 6). The augmentation of L-T3-effect by propranolol appeared to be a type of synergistic action and it might be due to some changes in the pre-synaptic membrane properties, the mechanism of which is unclear at present. However, clonidine $\left(\alpha_{2}\right.$-ADR agonist, and Gi-protein activator) (Figure 7) and glutamate (acts through metabotropic glutamate receptors and activator of Gi protein) (Figure 8) attenuated L-T3effect, suggesting its possible coupling with GPCR. Equimolar concentration of clonidine (1 nM $-100 \mathrm{nM}$ ) counteracted the inhibitory effect of L-T3 on the NKA activity (Figure 7). This counteraction by clonidine, $\alpha_{2}$-ADR agonist, appears to be mediated through the inhibition of adenylate cyclase activity with the activation of inhibitory $G$ protein $\left(\mathrm{G}_{\mathrm{i}}\right)$ followed by inhibition of cAMP synthesis and protein phosphorylation cascade mechanism. It is known that $\alpha_{2}$-adrenergic receptor agonist system act through $G_{i}$ protein activation [64]. 


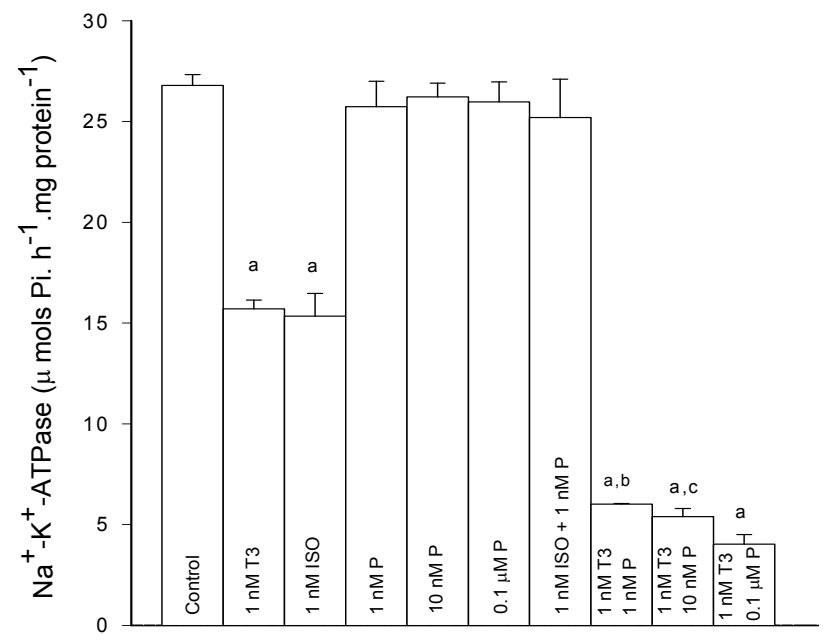

Figure 6. In vitro effect of L-T3, isoproterenol (ISO) and propranolol (P), on synaptosomal NKA activity.

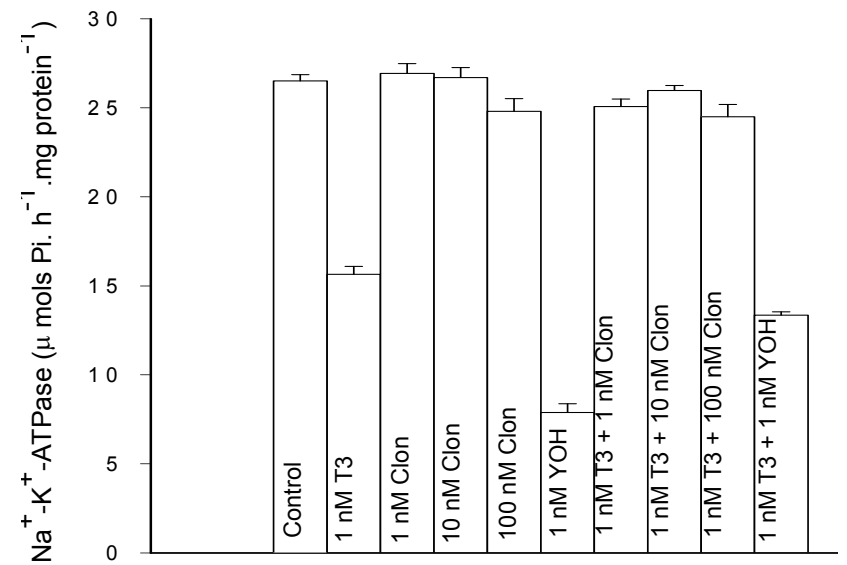

Figure 7. In vitro effect of L-T3, clonidine (CLON, and yohimbine (YOH, $\alpha_{2}-\mathrm{ADR}$ antagonist) on synaptosomal NKA activity.

Thus it seems that the L-T3 action could be ascribed more to stimulate Gs protein during beta-blockade which might be directed to manage this adverse condition. The results also suggest that the L-T3-effect on the synaptosomal NKA activity was not mediated via the $\beta$ ADR-dependent systems, since it was not blocked by propranolol. Based on these results it was also hypothesized that L-T3-effect would alter adenylate cyclase activity. In cultured neuroblastoma plasma membrane increased adenylate cyclase activity was noticed followed by L-T3-treatment [65]. In fact, later, increased adenylate cyclase activity was noticed in brain hypothyroid condition which increases brain L-T3 levels. This observation was correlated well with increased D-II activity to the increased brain L-T3 levels in brain hypothyroid situations [15]. Guanosine 5'-O-(3-thiotriphosphate) or pertussis toxin also has 
been reported to inhibit $\mathrm{TH}$-induced mitogen-activated protein kinase (MAPK) phosphorylation nongenomically in $293 \mathrm{~T}$ cells which is consistent with a cell membrane mechanism mediated via a G-protein [66]. 3-iodothyronine ( $\left.\mathrm{T}_{1} \mathrm{AM}\right)$, an endogenous and rapid-acting derivative of $\mathrm{TH}$, is associated with Gs-protein coupled-trace amine receptor TAR1 in HEK cells. However, no modulation of TH binding at appropriate guanylate nucleotide concentrations in adult brain has been reported [67]. Determination of whether activation or inactivation of a specific type(s) of G-protein influences TH-effects on protein phosphorylation is crucial.

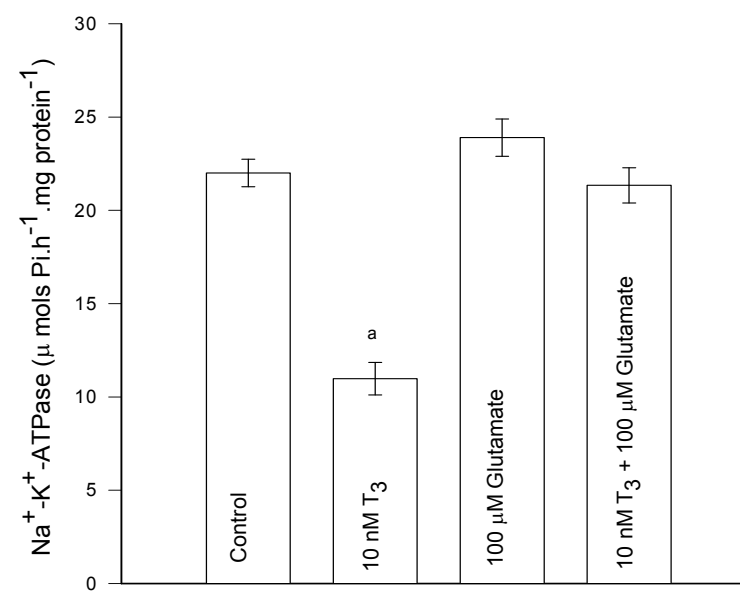

Figure 8. Attenuation of L-T3-effect on synaptosomal NKA activity by glutamate, in vitro.

A diverse nongenomic effect of $\mathrm{TH}$ has been observed in non-neural tissues including liver, heart, adipocytes, and blood [12,68]. Some possible nongenomic actions of THs include modulation of GABA uptake, regulation of NKA activity and increase of presynaptic $\mathrm{Ca}^{2+}-$ influx. In synaptoneurosomes TH inhibits the stimulation of chloride flux by GABA [69]. LT4 has been shown to stimulate the MAPK pathway in a variety of cultured cell lines including HeLa and CV-1 cells which lack functional nuclear TH receptors [66,70-73], consistent with a cell membrane mediated mechanism via G-proteins. L-T4 and L-T3 were found to inhibit Go-protein activities in synaptosomes from developing chick brain [48].

Direct interactions of $\mathrm{G}$ protein subunits with $\mathrm{Ca}^{2+}$-channels are not well documented. However, increased evidences showed receptor activated $G$ proteins modulate activities of ion channels by membrane-confined mechanisms [74]. Isoproterenol induced phosphorylation of ventricular $\mathrm{Ca}^{2+}$-channels via PKA has been reported [75]. Gs protein also has been shown to regulate $\mathrm{Ca}^{2+}$-channels both in a cAMP-independent membraneconfined mechanism [74] and in a cAMP-dependent phosphorylation of one of the subunits of L-type $\mathrm{Ca}^{2+}$-channel [76]. Synaptosomal NKA has previously been described to be inhibited by cAMP in a dose-dependent manner suggesting a role of PKA. The activated form of this protein kinase was further phosphorylated a substrate protein which in turn depressed the total $\mathrm{Na}^{+}$-dependent phosphorylation of the synaptosomal NKA [77]. Overall, 
our data indirectly support the involvement of second messenger system (cAMP and/or $\mathrm{Ca}^{2+}$ ) mediated through $\mathrm{G}$ protein activation after specific L-T3-membrane receptor interaction. The membrane NKA has been implicated in several aspects of physiologic processes including its role in neurotransmitter release [43].

\subsection{First evidence of rapid nongenomic action of thyroid hormone and its metabolites on the synaptosomal protein phosphorylation in adult rat brain, in vitro}

Protein phosphorylation and dephosphorylation are now recognized to be major regulatory mechanisms by which neural activities are controlled by external physiological signals or stimuli. Several nongenomic mechanisms are coordinated by rapid post-transcriptional modifications, such as protein phosphorylation and dephosphorylation reactions, which act like a molecular switch to control intracellular signaling mechanisms. Abnormalities of these imperative regulatory signaling processes produce deleterious effects on the CNS. As a consequence, variety in unusual protein phosphorylation is the end result of many major neuropshychological dysfunctions leading to diseases [78]. Numerous second messenger molecules regulate cellular physiology by effects on protein kinases and phosphatases. Protein kinases catalyze the transfer of the terminal $\gamma$-phosphate group of ATP or GTP to the hydroxyl group of serine, threonine or tyrosine in substrate proteins. Their structure, subcellular localization and substrate specificity allow them to control cellular physiology. These proteins largely make up the cell signaling pathways that transmit, amplify and integrate signals from the extracellular environment. Protein phosphorylation promotes enzyme activation or deactivation. Phosphorylated proteins are substrates for protein phosphatases and dephosphorylation occur to serve as a molecular switch to fine tune a cellular response [79].

Variety of agents regulating the activity of NKA raises the possibility of the NKA as a substrate molecule that is subject to regulation by phosphorylation or dephosphorylation. Indeed, inhibition of NKA is associated with the phosphorylation of the enzyme by both PKA and PKC. This inhibition of NKA has been attributed to the phosphorylation of $\alpha_{1-}$ subunit of the NKA molecule at serine residues by PKA and PKC site-specifically. Isoproterenol ( $\beta$-adrenergic agonist that activates adenylate cyclase to produce CAMP, an activator of PKA), forskolin (adenylate cyclase activator), and okadaic acid (an inhibitor of protein phosphatase-1 and $-2 \mathrm{~A}$ ) have been reported to increase significantly the level of phosphorylation of wild-type $\alpha_{1}$-subunit of the NKA in COS cells, accompanied by a significant inhibition of the enzyme activity [62,63]. Among nine distinct isoforms of adenylate cyclase (AC), three isoforms are $\mathrm{Ca}^{2+} /$ calmodulin-dependent, including type I-AC, III-AC [80,81], and VIII-AC. The $\mathrm{Ca}^{2+} /$ calmodulin-dependent AC is an integral membrane protein [82]. Hence, one possible role of $\mathrm{Ca}^{2+} /$ calmodulin may be to stimulate $\mathrm{Ca}^{2+} /$ calmodulin-dependent AC followed by cAMP production and phosphorylation of the NKA, exactly as $\beta$-adrenergic receptor agonists do. 
While a direct effect of $\mathrm{TH}$ on protein kinase activity has not been formerly studied in tissues from mature brain, hypothyroidism has been linked with reduced levels of phosphorylated MAPK in the hippocampus [83]. Based on these observations, possibility of a metabotropic pathway for rapid actions of $\mathrm{TH}$ on protein phosphorylation in synaptosomes from adult rat brain was investigated.

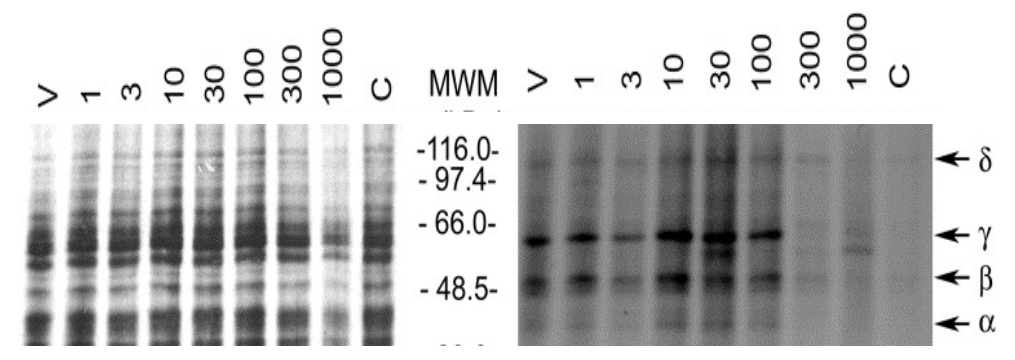

(a)

(b)

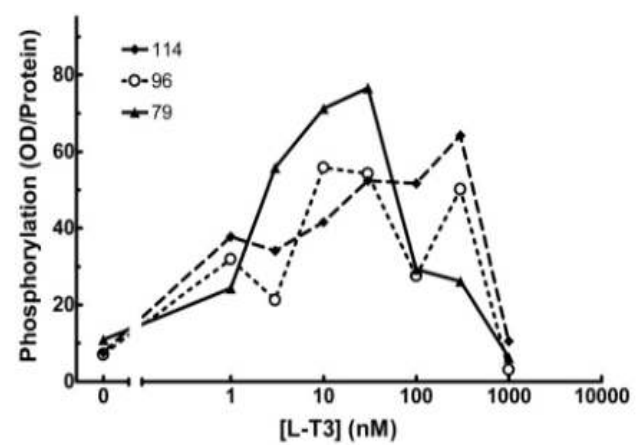

(c)

Figure 9. Representative autoradiogram of SDS-PAGE separation of proteins incorporating ${ }^{32} \mathrm{P}$ in the presence of L-T3. Lanes were loaded with synaptosomal lysates which had been preincubated at $0^{\circ} \mathrm{C}$ for $60 \mathrm{~min}$ and $37^{\circ} \mathrm{C}$ for $5 \mathrm{~min}$ with (from left): $1 \mathrm{mM} \mathrm{Na} \mathrm{VO}_{4}(\mathrm{~V}), 1,3,10,30,100,300,1000$, or 0 (C= control) nM L-T3 and then incubated with $20 \mu \mathrm{M}$ of $\left[\gamma^{-32} \mathrm{P}\right]-\mathrm{ATP}(3 \mu \mathrm{Ci})$ for $1 \mathrm{~min}$ at $37^{\circ} \mathrm{C}$. Left panel (a): Silver-stained gel for visualization of protein bands. Right panel (b): Autoradiogram of same gel showing increased incorporation of ${ }^{32} \mathrm{P}$ in four prominent bands $(\alpha: 38 \pm 1 \mathrm{kD}, \beta: 53 \pm 1 \mathrm{kD}, \gamma: 63 \pm 1 \mathrm{kD}, \delta$ : $113 \pm 1 \mathrm{kD}$ ). (c) Normalized data showing effect of in vitro addition of graded doses of L-T3 on the levels of protein phosphorylation expressed as optical density (OD)/protein (Ref. Sarkar et al. 2006 Neuroscience 137: 125-132 acknowledged [11]).

Our observation demonstrated that $\mathrm{TH}$ induces rapid changes in synaptosomal protein phosphorylation. Incubation with L-T3 or L-T4 specifically showed significant biphasic dose-dependent effects on the phosphorylation of $38 \pm 1,53 \pm 1,62 \pm 1$, and $113 \pm 1 \mathrm{kD}$ proteins. In vitro brain physiologic concentrations of $\mathrm{TH}(1-30 \mathrm{nM})$ showed significant increase in the levels of protein phosphorylation rapidly within minutes (Figure 9). In contrast, incubations with similar doses of reverse-T3 (rT3) were without significant effect, indicating specificity for L-T3 and L-T4. The protein phosphorylation statuses of these four synaptosomal 
proteins were significantly increased followed by L-T3 and L-T4 treatment as well. Both LT3 and L-T4 indicated bi-phasic nature of effect for each of these proteins phosphorylated. Maximum levels of phosphorylation were noticed at concentration range from 10-30 nM. However, no significant effect on protein phosphorylation was observed as an effect of rT3 on any of these proteins. This effect of rT3 clearly confirmed very structural and functional specificity of L-T3 on protein phosphorylation. Determination of time course of protein phosphorylation followed by one single in vitro dose of L-T3 showed it peaked rapidly between 180 seconds to 240 seconds and thereafter it decreased. This indicated a rapid action of THs and its metabolites [11].

Our next interest was to see which amino acids present in these phosphoyraled proteins are targets. Hence phospho-specifc antibodies for tyrosine and serine were used in western bolt analysis. Immunoblot analysis of synaptosomal lysates incubated with L-T3 (1 nM-1 $\mu \mathrm{M})$ confirmed phosphorylation at the seryl residues of a $\sim 112 \mathrm{kD}$ protein and phosphorylation at tyrosyl residues of a distinct $\sim 95 \mathrm{kD}$ protein. These data support that THs have a diversity of rapid nongenomic pathways for regulation of protein phosphorylation in mature mammalian brain [11]. Especially, the $\alpha$-subunit of NKA is a $\sim 112 \mathrm{kD}$ membrane protein. Indeed, inhibition of NKA is associated with the phosphorylation of its subunits by both PKA and PKC. This inhibition of NKA has been attributed to the site-specific phosphorylation of the $\alpha_{1}$-subunit of the NKA at seryl residues by PKA and PKC [61-63]. In adult rat alveolar epithelial cell L-T3 induced translocation of NKA to plasma membrane. NKA stimulation by L-T3 was assigned to L-T3-induced stimulation of PI3K/PKB pathway via the Src family of tyrosine kinases nongenomically [84]. These data suggest possible involvement of membrane components in $\mathrm{TH}$-induced protein phosphorylation.

Examples of nongenomic control of protein phosphorylation by L-T3 also have been reported in few other tissues. Nongenomic relationship of MAPK and MAPK-mediated protein phosphorylation at the seryl residue of nuclear $\mathrm{TH}$ receptor has been described in 293 T cells [68]. This indicated a control of nongenomic mechanism on genomic mechanism. In developing brain, inhibition of PKA transcriptionally blocked L-T3-induced actin gene expression, whereas PKC and tyrosine kinase did not influence it significantly [85].

\subsubsection{Thyroid hormones rapidly modulate synaptosomal protein phosphorylation via second messenger systems}

In other studies, L-T3 induction has also been shown to nongenomically regulate $\mathrm{Ca}^{2+}$ influx and nitric oxide synthase activity within seconds in adult rat brain [57]. Thus, THs are likely to have numerous rapid nongenomic effects on signaling mechanisms in neural tissue, including alterations in the levels of intracellular second messengers (cAMP and $\mathrm{Ca}^{2+}$ ) which regulate cAMP- and/or $\mathrm{Ca}^{2+} /$ calmodulin $(\mathrm{CaM})$-dependent protein kinases leading to protein phosphorylation. Effects of $\mathrm{TH}$ on $\mathrm{Ca}^{2+}$-dependent activation of $\mathrm{PKC}$ and/or $\mathrm{Ca}^{2+} / \mathrm{CaM}-$ dependent protein kinases are also possible, followed by direct or indirect activation of phosphorylation of the proteins. Thus further investigation demonstrated for the first time the rapid nongenomic second messenger mediated regulation of protein phosphorylation by 
TH in mature mammalian brain and provided additional support for the contention that TH has a unique and complex signaling function in adult brain [12].

\subsubsection{Role of calcium and calmodulin on synaptosomal protein phosphorylation, in vitro}

Many nongenomic mechanisms are modulated by phosphorylation-dephosphorylation of substrate proteins. Multiple $\mathrm{Ca}^{2+} /$ calmodulin (CaM)-dependent protein kinases (CaM kinases) and $\mathrm{Ca}^{2+} /$ phospholipid-dependent protein kinases (PKCs) have been identified in brain. Among these, CaMPK-II is the most abundant $\mathrm{Ca}^{2+} / \mathrm{CaM}$-stimulated protein kinase in brain. CaMPK-II is important in several neuronal functions, including neurotransmitter release and the modulation of the functional properties of ion channels and receptors. CaMPK-II is differentially expressed in different brain regions of cells, exists in both cytosolic and membrane-associated forms and is especially concentrated in the postsynaptic density and synaptic vesicles. A distinct property of CaMPK-II is that autophosphorylation of its threonine residue near the calmodulin binding domain converts it to a $\mathrm{Ca}^{2+}-$ independent state. Further, it has been shown that calmodulin-dependent autophosphorylation of CaMPK-II induces a conformational changes in the region of the calmodulin binding domain that allows additional stabilizing interactions with calmodulin. This autophosphorylation may involve in extending the effects triggered by a transient calcium signal. PTU-induced mild hypothyroidism in chick brain during posthatch development has been shown to increase the level of $\mathrm{Ca}^{2+} / \mathrm{CaM}$-stimulated phosphorylation in cytosol, but lower it in the membrane, indicating a role of thyroid hormones in distributing CaMPK-II during developmental changes $[78,86]$.

\subsection{Effect of L-T3 on total protein phosphorylation}

The effect of $\mathrm{Ca}^{2+}$ and calmodulin on TH-induced total protein phosphorylation and their regulation was explored. L-T3 significantly and dose-dependently $(10 \mathrm{nM}-1 \mu \mathrm{M})$ increased total ${ }^{32} \mathrm{P}$ - incorporation into synaptosomal proteins, in vitro, over the basal level of phosphorylation. Although L-T3 exerted its own independent effect on increase in overall total protein phosphorylation, specifically it established its role to be at least dependent on $\mathrm{Ca}^{2+}$ and calmodulin. $\mathrm{Ca}^{2+}$ also showed its independent influence on the basal L-T3-induced total protein phosphorylation in synaptosomal isolates. The dependency of L-T3-induced total synaptosomal protein phosphorylation was evaluated and finally confirmed using EGTA ( $\mathrm{Ca}^{2+}$-ion chelator) and KN-62 (a specific blocker of CaMK-II). In vitro addition of 10 $\mathrm{nM}$ and $100 \mathrm{nM}$ doses of L-T3 alone did not alter significantly the basal levels of phosphorylation. However, the $1 \mu \mathrm{M}$ dose of L-T3 significantly amplified the signal by $\sim 1.3-$ fold compared to the basal level $(\mathrm{P}<0.05)$. Next, we wanted to determine whether $\mathrm{Ca}^{2+}$ augments protein phosphorylation in the presence of L-T3. $\mathrm{Ca}^{2+}(0.5 \mathrm{mM})$ were able to significantly increase the basal phosphorylation level. However, no further significant changes were noticed with additional $10 \mathrm{nM}$ or $100 \mathrm{nM}$ L-T3. However, $1 \mu \mathrm{M}$ concentration of L-T3 augmented the signal significantly $(\mathrm{P}<0.05)$ by $\sim 1.5$-fold $(0.2167 \mathrm{pmols} / \mathrm{min} / \mathrm{mg}$ protein) as compared to the $\mathrm{Ca}^{2+}$-treated baseline $(0.1475 \mathrm{pmols} / \mathrm{min} / \mathrm{mg}$ protein), and by 2.2-fold over the basal phosphorylation $(0.097 \mathrm{pmols} / \mathrm{min} / \mathrm{mg}$ protein $)$. In contrast, the effects of low physiological concentrations of L-T3 were dramatically enhanced when $2 \mu \mathrm{M}$ $\mathrm{CaM}$ was added to the $\mathrm{Ca}^{2+}+\mathrm{L}-\mathrm{T} 3-$ treatment group. In the presence of $\mathrm{Ca}^{2+}$ and $\mathrm{CaM}, \mathrm{L}-\mathrm{T} 3$ 
$(10 \mathrm{nM}-1 \mu \mathrm{M})$ induced a dose-dependent increase in ${ }^{32} \mathrm{P}$ - incorporation into synaptosomal protein, by $47 \pm 8,74 \pm 13$ and $52 \pm 11 \%(\mathrm{~F}=6.77, \mathrm{P}<0.0001)$ rapidly within 1 min compared with the $\mathrm{Ca}^{2+} / \mathrm{CaM}$-treated control phosphorylation (0.189 $\mathrm{pmols} / \mathrm{min} / \mathrm{mg}$ protein) [87].

Physiological concentrations L-T3 in nerve terminals are difficult to measure. Predictable levels of L-T3 within the nerve terminals range from $\sim 10 \mathrm{nM}$ to $64 \mathrm{nM}$. PTU-induced peripheral hypothyroidism in adult rats showed endogenous synaptosomal level of L-T3 is about $\sim 126 \mathrm{nM}$. Thus L-T3 $(1 \mu \mathrm{M})$ is well above this range, and would be considered to have a more pharmacological type of action on ${ }^{32} \mathrm{P}$ - incorporation to synaptosomal phosphoproteins. Treatment with agents regulating $\mathrm{Ca}^{2+}$ could be a potential strategy for enhancing clinical treatment of conditions, such as certain affective disorders, which may be responsive to pharmacological doses of TH. In an earlier in vitro study, L-T3 doses (0.1 to $100 \mathrm{nM}$ ), have been shown to induce an increase in intrasynaptosomal $\mathrm{Ca}^{2+}$ levels with an optimum at $100 \mathrm{nM}$ of L-T3. Although higher levels of L-T3 $(1 \mu \mathrm{M})$ produced slight depression of intrasynaptosmal $\mathrm{Ca}^{2+}$ levels, picomolar levels of L-T3 were also shown to be able to significantly increase intrasynaptosomal $\mathrm{Ca}^{2+}$ levels in vitro. The synergistic effect of L-T3 and $\mathrm{Ca}^{2+} / \mathrm{CaM}$ on protein phosphorylation would likely be further amplified by the effect of L-T3 to increase $\mathrm{Ca}^{2+}$ levels intracellularly in the physiological situation. In particular, this study demonstrated that of $10 \mathrm{nM}$ dose of L-T3 (brain physiological concentration) and a ten times higher dose of L-T3 (as observed to be the brain levels of L-T3 in PTU-induced hypothyroid young adult rat brain synaptosomes alone or with $\mathrm{Ca}^{2+}$ did dramatically increased L-T3-induced total protein phosphorylation. Thus the present study demonstrated that $\mathrm{Ca}^{2+} / \mathrm{CaM}$-dependent mechanisms synergistically increase the rapid nongenomic effect of L-T3 on synaptosomal protein phosphorylation [87]. The $\mathrm{Ca}^{2+} / \mathrm{CaM}-$ dependent effects could be due to an activation of an unknown CaM-dependent protein kinase(s), deactivation of protein phosphatase(s) or a combination of effects. However, it proved to be highly sensitive to L-T3 activation.

Numerous phosphoproteins are greatly influenced by PKA and PKC in a $\mathrm{Ca}^{2+}$ - and/or CaMdependent way. Often $\mathrm{Ca}^{2+}$ also functions in combination with $\mathrm{CaM}$ or with phosphoinositides/diacylglycerol to induce additional signal transduction pathways within the synaptic network. Regulation of intracellular $\mathrm{Ca}^{2+}, \mathrm{CaM}$ and subsequent protein phosphorylation are important for brain and cognitive functions affected by various psychiatric disorders. Membrane depolarization-induced $\mathrm{Ca}^{2+}$-influx activates extracellularly regulated kinases/MAPK in a $\mathrm{Ca}^{2+} / \mathrm{CaM}$-dependent way in PC12 cells. THs also promote MAPK-mediated serine phosphorylation of the nuclear TH receptor $\beta-1$ isoform nongenomically in $293 \mathrm{~T}$ cells. $\mathrm{Ca}^{2+}$ and CaM also differentially regulate of $\mathrm{TH}-$ induced neuronal protein phosphorylation $[12,87]$.

\subsection{L-T3-induced stimulation of phosphorylation of 63- and $53 \mathrm{kD}$ proteins was} regulated by $\mathrm{Ca}^{2+}$ and calmodulin

After getting an idea of L-T3-induced total protein phosphorylation within neuronal membrane it was an obvious interest to look for specific proteins phosphorylated under the influence of L-T3. In vitro addition of L-T3 (10 nM, brain physiologic concentrations of L-T3) 
demonstrated differential regulation of phosphorylation status of five different synaptosomal proteins (63-, 53-, 38-, 23-, and $16 \mathrm{kD}$ ) in both a $\mathrm{Ca}^{2+} / \mathrm{CaM}-$ dependent and independent manner in mature rat brain cortical synaptosomes. L-T3 increased the level of phosphorylation of all these five proteins. $\mathrm{Ca}^{2+} / \mathrm{CaM}$ further stimulated phosphorylation of 63- and $53 \mathrm{kD}$ proteins by L-T3, which were inhibited both specifically by EGTA $\left(\mathrm{Ca}^{2+}-\right.$ chelator) or KN62 ( $\mathrm{Ca}^{2+} / \mathrm{CaM}$ kinase-II [CaMK-II] inhibitor), suggesting the role of CaMK-II. However, presence of $\mathrm{Ca}^{2+}$ significantly decreased L-T3-induced phosphorylation of 63-, 53 $\mathrm{kD}$ proteins (Figure 10).

A
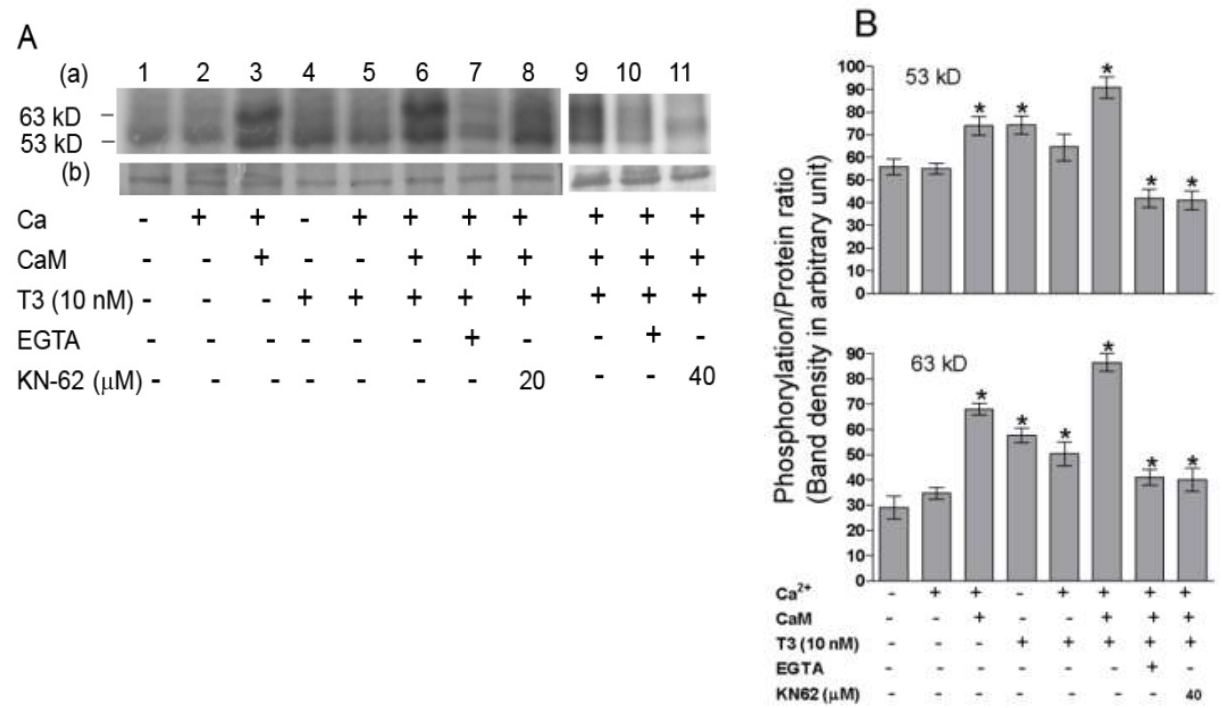

Figure 10. A. L-T3-stimulated phosphorylation of $63-$ and $53 \mathrm{kDa}$ proteins are regulated by $\mathrm{Ca}^{2+} / \mathrm{CaM}-$ dependent protein kinase II. (a) Representative autoradiogram of the 63- and 53 KD proteins followed by various treatment conditions as described. (b) Corresponding protein bands from silver stained gel used for normalization of the data and demonstrates comparable equal amounts of sample loading. B. The quantification of the L-T3 $(10 \mathrm{nM})$-induced phosphorylation presented as a graph of ratio of the band densities of the phosphorylated proteins in the autoradiogram (a) and the corresponding protein in the silver stained gel (b) at different treatment conditions as indicated. ${ }^{*}$ represents the level of significance of $\mathrm{P}<0.05$ compared to the corresponding basal level (control). The data presented are normalized results (mean \pm S.E.M.) for an indicated protein band (Ref. Sarkar 2008 Life Sciences 82: 920927 acknowledged [12]).

5.4.1.1.3. Inert action of $\mathrm{Ca}^{2+}$ and calmodulin on the independent effect of L-T3 on the phosphorylation of 38- and $23 \mathrm{kD}$ proteins

L-T3 also increased the phosphorylation of 23- and $38 \mathrm{kD}$ proteins. The effect was independent of EGTA or KN62. L-T3 only slightly enhanced the phosphorylation of the 38 $\mathrm{kD}$ protein $(\mathrm{p}<0.05, \mathrm{~F}=3.74)$ by $\sim 1.2$-fold in the presence of $\mathrm{Ca}^{2+} / \mathrm{CaM}$ compared to $\mathrm{Ca}^{2+} / \mathrm{CaM}$ control group. Although addition of $\mathrm{Ca}^{2+}$ decreased the level of L-T3-induced phosphorylation of $38 \mathrm{kD}$ protein $(\mathrm{P}=$ non-significant), it was significantly increased 
$(\mathrm{P}<0.05)$ in the presence of $\mathrm{CaM}$ compared to $\mathrm{Ca}^{2+}+\mathrm{L}-\mathrm{T} 3$ treatment and only L-T3 effect. However, the presence of $\mathrm{Ca}^{2+}$ or the $\mathrm{Ca}^{2+} / \mathrm{CaM}$ did not further affect the phosphorylation status of the $38 \mathrm{kD}$ protein. This further suggested no involvement of $\mathrm{Ca}^{2+} / \mathrm{CaM}$-dependent pathways mediated through CaMK-II.

The study also described the phosphorylation status of a $23 \mathrm{kD}$ protein. Phosphorylation level of $23 \mathrm{kD}$ protein was highest among all the proteins. L-T3 significantly increased the phosphorylation level of $23 \mathrm{kD}$ by $\sim 2.2$-fold compared to the basal level. Especially of interest, EGTA or KN62 did not show any more or less influence on the L-T3-induced increase in the phosphorylation status of the $23 \mathrm{kD}$ protein suggesting lack of significant regulation by CaMK-II (Figure 11).
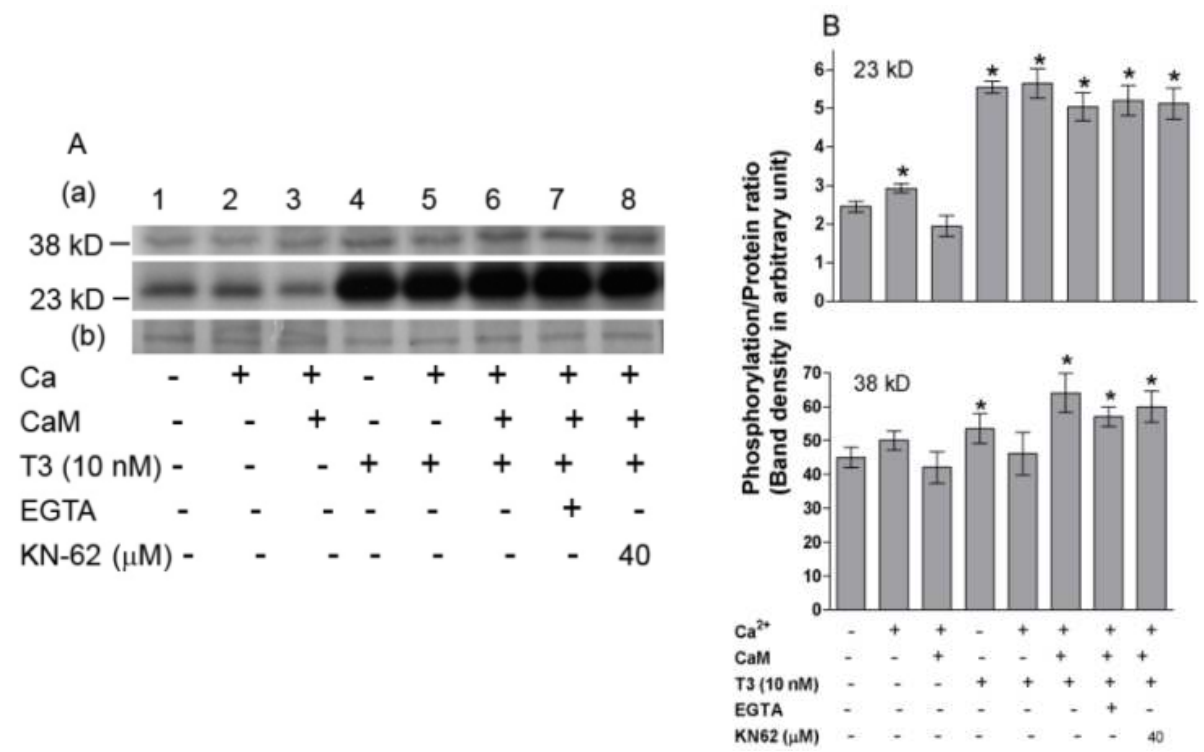

Figure 11. A. $\mathrm{Ca}^{2+} / \mathrm{CaM}$ do not modulate L-T3-stimulated phosphorylation of 23 - and $38 \mathrm{kD}$ proteins. (a) A representative autoradiogram of the 23 - and $38 \mathrm{kD}$ protein separated by SDS-PAGE showing independent stimulatory action of L-T3 upon the phosphorylation of the $23-$ and $38 \mathrm{kD}$ proteins. $\mathrm{B}$. The quantification of the L-T3-induced phosphorylation presented as a graph of ratio of the band densities of the phosphorylated proteins in the autoradiogram (a) and the corresponding protein in the silver stained gel (b) at different treatment conditions as indicated. The data presented are normalized results (mean \pm S.E.M.) for an indicated protein band. * Indicates levels of significance $\mathrm{P}<0.05$ (Ref. Sarkar 2008 Life Sciences 82: 920-927 acknowledged [12]).

\subsection{Calmodulin dephosphorylated $16 \mathrm{kD}$ protein following L-T3-induction}

In vitro addition of L-T3 $(10 \mathrm{nM})$ significantly increased the level of phosphorylation of 16 $\mathrm{kD}$ protein by $\sim 8$-fold. The L-T3-induced phosphorylation of $16 \mathrm{kD}$ protein was not further activated in the presence of $\mathrm{Ca}^{2+}$. Surprisingly, L-T3-induced phosphorylation of $16 \mathrm{kD}$ protein was not augmented further with $\mathrm{Ca}^{2+}$ or $\mathrm{Ca}^{2+} / \mathrm{CaM}$; instead, the presence of $\mathrm{CaM}$ 
abolished the L-T3-induced phosphorylation. EGTA or KN62 could not restore the effect of CaM-induced dephosphorylation of this protein (Figure 12).

Immunoblotting experiment with anti-phosphoserine antibodies also showed significant enhancement of seryl residue phosphorylation of this protein by $\mathrm{Ca}^{2+} / \mathrm{CaM}$ (Figure 13). Abolition of this effect by EGTA and KN-62 further suggested an important role of CaMK-II. This study identified the role of $\mathrm{Ca}^{2+} / \mathrm{CaM}$ in the regulation of $\mathrm{L}$-T3-induced protein phosphorylation and supported a unique nongenomic mechanism of second messengermediated regulation of protein phosphorylation by $\mathrm{TH}$ in mature rat brain.
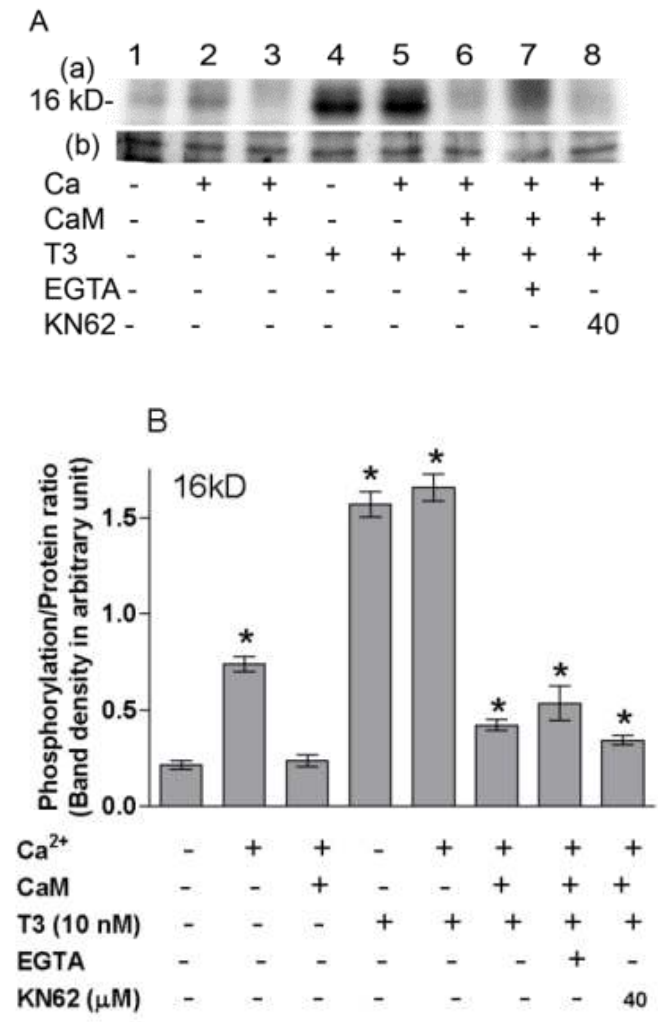

Figure 12. A. Phosphorylation of $16 \mathrm{kD}$ protein by L-T3 was conquered by the dephosphorylation activity of CaM. (a) A representative autoradiogram of the $16 \mathrm{kD}$ protein separated by SDS-PAGE is showing independent stimulatory action of L-T3 upon the phosphorylation of the $16 \mathrm{kD}$ protein. (b). Corresponding protein bands of silver stained gel. B. The quantification of the L-T3 (10 nM)-induced phosphorylation and its dephosphorylation by CaM are presented as a graph of ratio of the band densities of the phosphorylated proteins in the autoradiogram (a) and the corresponding protein in the silver stained gel (b) at different treatment conditions as indicated. The data presented are normalized results (mean \pm S.E.M.) for an indicated protein band. * Indicates levels of significance $\mathrm{P}<0.05$, compared to the basal level (control group) (Ref. Sarkar 2008 Life Sciences 82: 920-927 acknowledged [12]). 
(A)

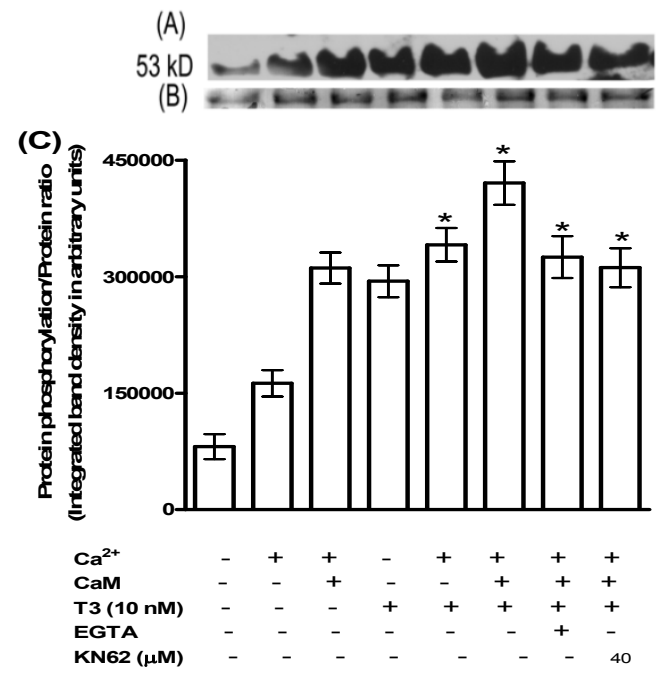

Figure 13. $\mathrm{L}-\mathrm{T} 3$ induced phosphorylation of the $53 \mathrm{kD}$ protein is regulated by $\mathrm{Ca}^{2+} / \mathrm{calmodulin}$ protein kinase II: Serine residue phosphorylation. (A) Phosphorylation status of the $53 \mathrm{kD}$ protein immunoblotted with anti-phosphoserine (PS) antibody. (B) Corresponding protein band of silver stained gel. (C) Graphical representation of the levels of phosphorylation of the $53 \mathrm{kD}$ protein at various treatment conditions. The data presented are normalized results (mean \pm S.E.M.) for an indicated protein band. * Indicates levels of significance $\mathrm{P}<0.05$, compared to the basal level (control group).

\subsubsection{Role of cAMP on synaptosomal protein phosphorylation, in vitro}

After searching for whether $\mathrm{Ca}^{2+}$ plays a major role as second messenger following L-T3 induced protein phosphorylation, our next step was to examine for the role of cyclic AMP (cAMP) as another second messenger upon L-T3-induction, in vitro, to explore furthermore the nongenomic mechanism of TH. To search for any role of cAMP-dependent protein kinase (PKA) the effects of cAMP and H7 (a specific blocker of PKA) were studied. In vitro addition of H7 significantly diminished the effect of L-T3-induced increase in serine phosphorylation of two closely associated proteins with 51 - and $53 \mathrm{kD}$ by $\sim 14$-fold and $\sim 11$ fold respectively (Figure 14). This suggested prevalence of a PKA-mediated mechanism in L-T3-induced synaptosomal protein phosphorylation. To test further whether THs exert adrenergic-like actions by binding to or modulating adrenergic receptor activities another study was performed to test this hypothesis. The idea of formation of thyronamines and its possible binding to the ADR is considered here. Effect of clonidine was studied on the L-T3induced protein phosphorylation and on the L-T3-binding to the synaptosomal membrane receptors. Scatchard plot analysis revealed clonidine and yohimbine ( $\alpha_{2}$-ADR antagonist) could not alter specific L-T3 binding at the high affinity L-T3 synaptosomal membrane binding sites. L-T3 induced phosphorylation of this $51-/ 53 \mathrm{kD}$ protein was blocked by H7, a PKA inhibitor. Activation of $\alpha_{2}$-ADR by clonidine normally decreases the levels of cAMP via inhibiting adenylate cyclase activity. Possibly in the absence of adequate cAMP levels during clonidine treatment, the phosphorylation status of the $51-/ 53 \mathrm{kD}$ protein remained 
unchanged. This suggests L-T3-membrane interaction was independent of the activation of the $\alpha_{2}$-ADR system. Overall these data implicate that PKA and CaMK-II both contribute for L-T3 regulated protein phosphorylation in adult mammalian brain and reveals a nongenomic mechanistic pathway in relation to higher mental functions.

(A) $\mathrm{kD}$

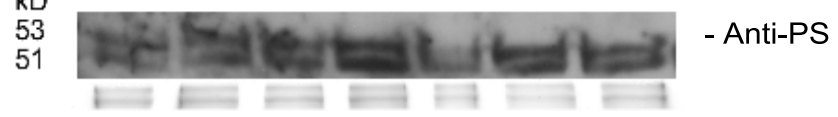

(B)

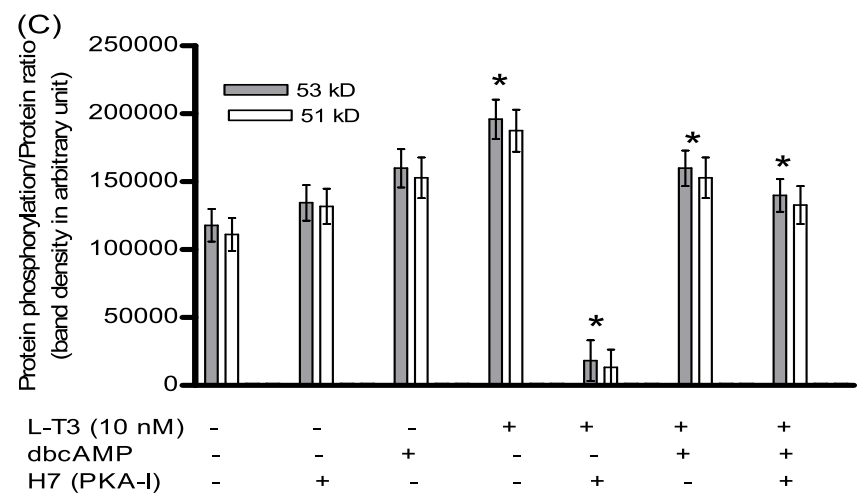

Figure 14. L-T3 induced phosphorylation of the 51-/53- kD proteins are abolished by Protein Kinase A Inhibitor (H7). (A) One representative phosphorylation status of the 51-/53-kD protein immunoblotted with anti-phosphoserine (PS) antibodies. (B) Corresponding protein band of silver stained gel. (C) Graphical representation of the levels of phosphorylation of the $51-/ 53-\mathrm{kD}$ protein at various treatment conditions. dbcAMP is dibutyryl cyclic AMP. The data presented are normalized results (mean \pm S.E.M.) for an indicated protein band. ${ }^{*}$ Indicates levels of significance $p<0.05$, compared to the basal level (control group).

\section{Conclusion}

In conclusion the recent evidence-based information regarding the nongenomic mechanism of action of THs are opening new signal transduction clues to be studied and to reveal the underlying mechanism in mature mammalian brain. The results of the study conducted will advance our knowledge of the fundamental molecular mechanism of $\mathrm{TH}$ action in mature CNS, likely in future will lead to more rational and effective approach to the development of novel therapeutic agents, and thus will shed insights on to the neuropshychological manifestations of adult on-set thyroid disorders in humans, particularly in relation to higher mental functions. 


\section{Future research direction}

Recent information regarding nongenomic mechanism of thyroid hormone action in various tissue types including mammalian CNS is interesting. These studies are diligently engaged in decoding the molecular consequences of thyroid hormone action from the specific gene expression to the nongenomic rapid actions of the hormone. Open-minded investigators are desperately searching for the truth and the relationship of thyroid hormone action explicated through its classical well-known doctrine which is mediated via activation of specific nuclear receptors to the newly emerging idea of rapid nongenomic actions of the hormone and an association to enlighten the both. In particular, adult mammalian brain are of best curiosity since clinical observations of numerous thyroid dysfunction related neuropsychological disorders produced during mature conditions in humans can be corrected with the adjustment of the thyroid hormone levels. However the mechanism of action is lacking. Nongenomic rapid events mediated by thyroid hormones could have connection to the long-term genomic actions. Deciphering the nongenomic molecular mechanism of action of thyroid hormones has future prospects to study its importance regulating higher mental functions in humans. This fundamental knowledge could be the basis to find novel strategies to treat adult-onset thyroid dysfunctions including neuropsychological diseases many of which are precisely controlled by demarcated cellular fine-tuning of the protein phosphorylation mechanisms related to neuronal signal transmission.

\section{Author details}

Pradip K. Sarkar

Department of Basic Sciences, Parker University, Dallas, Texas, USA

\section{Acknowledgement}

Financial support was provided by Parker University, Dallas, Texas, USA.

\section{References}

[1] Sarkar PK (2002) In quest of thyroid hormone function in mature mammalian brain. Indian J. Exp. Biol. 40(8): 865-873.

[2] Oetting A, Yen PM (2007) New insights into thyroid hormone action. Best Pract. Res. Clin. Endocrinol. Metab. 21:193-208.

[3] Cheng SY, Leonard JL, Davis PJ (2010) Molecular aspects of thyroid hormone actions. Endocr. Rev. 31: 139-170.

[4] Davis PJ, Davis FB (1996) Nongenomic actions of thyroid hormone. Thyroid 6: 497-504.

[5] Haggerty JJ, Jr., Prange AJ, Jr. (1995) Borderline hypothyroidism and depression. Annu. Rev. Med.46: 37-46. 
[6] Bauer M, London ED, Silverman DH, Rasgon N, Kirchheiner J, Whybrow PC (2003) Thyroid, brain and mood modulation in affective disorder: insights from molecular research and functional brain imaging. Pharmacopsychiatry 36: S215-S221.

[7] Laurberg P (1990) Hypothyroidism In: Greer MA, editor. The Thyroid Gland. New York: Raven Press, p. 497-535.

[8] Utiger RD (1987) Hyperthyroidism. In: Green WL, editor. The Thyroid. New York: Elsevier, p. 157-218.

[9] Hoefig CS, Renko K, Piehl S, Scanlan TS, Bertoldi M, Opladen T, Hoffmann GF, Klein J, Blankenstein O, Schweizer U, Kohrle (2012) Does the aromatic L-amino acid decarboxylase contribute to thyronamine biosynthesis? Mol. Cell. Endocrinol. 349: 195201.

[10] Gompf HS, Greenberg JH, Aston-Jones G, Ianculescu AG, Scanlan TS, Dratman MB (2010) 3-Monoiodothyronamine: the rationale for its action as an endogenous adrenergic-blocking neuromodulator. Brain Res. 1351:130-140.

[11] Sarkar PK, Durga ND, Morris JJ, Martin JV (2006) In vitro thyroid hormone rapidly modulates protein phosphorylation in cerebrocortical synaptosomes from adult rat brain. Neurosci. 137: 125-132.

[12] Sarkar PK (2008) L-triiodothyronine differentially and nongenomically regulates synaptosomal protein phosphorylation in adult rat brain cerebral cortex: role of calcium and calmodulin. Life Sci. 82: 920-927.

[13] Sarkar PK, Ray AK (1994) Synaptosomal T3 content in cerebral cortex of adult rat in different thyroidal states. Neuropsychopharmacol. 11: 151-155.

[14] Kundu S, Pramanik M, Roy S, De J, Biswas A, Ray AK (2006) Maintenance of brain thyroid hormone level during peripheral hypothyroid condition in adult rat. Life Sci. 79: 1450-1455.

[15] Kundu S, Biswas A, Roy S, De J, Pramanik M, Ray AK (2009) Thyroid hormone homeostasis in brain: possible involvement of adrenergic phenomenon in adult rat. Neuroendocrinol.89: 140-151.

[16] Sarkar PK (2010) Subcellular levels of L-T3 and L-T4 in adult rat brain cerebral cortex. Thyroid Sci. 5: 1-4.

[17] Sarkar PK, Ray AK (1992) A simple biochemical approach to differentiate synaptosomes and non-synaptic mitochondria from rat brain. Methods Find. Exp. Clin. Pharmacol. 14: 493-497.

[18] Dratman MB, Crutchfield FL, Axelrod J, Colburn RW, Thoa N (1976) Localization of triiodothyronine in nerve ending fractions of rat brain. Proc. Natl. Acad. Sci. U S A 73: 941-944.

[19] Dratman MB, Crutchfield FL (1978) Synaptosomal [125I]triiodothyronine after intravenous [125I]thyroxine. Am. J. Physiol. 235: E638-E647.

[20] Dratman MB, Crutchfield FL, Futaesaku Y, Goldberger ME, Murray M (1987) $\left[{ }^{125} \mathrm{I}\right]$ Triiodothyronine in the rat brain: Evidence for neural localization and axonal transport derived from thaw-mount film autoradiography. J. Comp. Neurol. 260: 392408. 
[21] Dratman MB, Futaesaku Y, Crutchfield FL, Berman N, Payne B, Stumpf WE, Sar M (1982) Iodine ${ }^{125}$-labeled triiodothyronine in rat brain: Evidence for localization in discrete neural systems. Science 215: 309-312.

[22] Dratman MB, Crutchfield FL, Gordon JT, Jennings AS (1983) Iodothyronine homeostasis in rat brain during hypo- and hyperthyroidism. Am. J. Physiol. 245: E189E193.

[23] Mason GA, Walker CH, Prange AJ (1993) L-Triiodothyronine: Is this peripheral hormone a central neurotransmitter? Neuropsychopharmacol. 8: 253-258.

[24] Kastellakis A, Valcana T (1989) Characterization of thyroid hormone transport in synaptosomes of rat cerebral cortex. Mol. Cell. Endocrinol. 67: 231-241.

[25] Visser WE, Friesema EC, Visser TJ (2011) Minireview: thyroid hormone transporters: the knowns and the unknowns. Mol. Endocrinol. 25: 1-14.

[26] Kinne A, Schulein R, Krause G (2011) Primary and secondary thyroid hormone transporters. Thyroid Res. 4: S7.

[27] Constantinou C, Margarity M, Valcana T (2005) Region-specific effects of hypothyroidism on the relative expression of thyroid hormone receptors in adult rat brain. Mol. Cell. Biochem. 278: 93-100.

[28] Bolaris S, Constantinou C, Valcana T, Margarity M (2005) Pentylenetetrazole-induced convulsions affect cellular and molecular parameters of the mechanism of action of triiodothyronine in adult rat brain. Neuropharm 48: 894-902.

[29] Crantz FR, Silva JE, Larsen PR (1982) An analysis of the sources and quantity of 3,5,3'triiodothyronine specifically bound to nuclear receptors in rat cerebral cortex and cerebellum. Endocrinol. 110: 367-375.

[30] Halperin Y, Shapiro LE, Surks MI (1994) Down-regulation of type II L-thyroxine, 5'monodeiodinase in cultured GC cells: different pathways of regulation by Ltriiodothyronine and 3,3',5'-triiodo-L-thyronine. Endocrinol. 135: 1464-1469.

[31] Guadano-Ferraz A, Escamez MJ, Bernal J (1999) Expression of type 2 iodothyronine deiodinase in hypothyroid rat brain indicatesan important role of thyroid hormone in the development of specific primary sensory systems. J. Neurosci. 19: 3430.

[32] Biswas A, Kundu S, Roy S, De J, Pramanik M, Ray AK (2006) Thyroid hormone profile during annual reproductive cycle of diploid and triploid catfish, Heteropneustes fossilis (Bloch). Gen. Comp. Endocrinol. 147: 126-132.

[33] Soboll S (1993) Thyroid hormone action on mitochondrial energy transfer. Biochim. Biophys. Acta 1144: 1-16.

[34] Leonard JL, Kaplan TJ, Visser JE, Silva JE, Larsen PR (1981) Cerebral cortex responds rapidly to thyroid hormone. Science 214: 571-573.

[35] Leonard JL, Silva JE, Kaplan MM, Mellen SA, Visser TJ, Larsen PR (1984) Acute posttranscriptional regulation of cerebrocortical and pituitary iodothyronine 5'deiodinases by thyroid hormone. Endocrinol. 114: 998-1004.

[36] Serrano-Lozano A, Morata P, Montiel M, Perez-Aguilar JP, Morell M (1991) L-thyroxine and L-triiodothyronine in the cerebral tissues of the adult rat. Effect of hypothyroidism. Rev. Esp. Fisiol. 47: 141-145. 
[37] Crantz FR, Larsen PR (1980) Rapid thyroxine to 3,5,3'-triiodothyronine conversion and nuclear 3,5,3'-triiodothyronine binding in rat cerebral cortex and cerebellum. J. Clin. Invest. 65: 935-938.

[38] Kaplan MM, Yaskoski KA (1980) Phenolic and tyrosyl ring deiodination of iodothyronines in rat brain homogenates. J. Clin. Invest. 66: 551-562.

[39] Morreale de Escobar G, Calvo R, Escobar del Rey F, Obregon MJ (1994) Thyroid hormones in tissues from fetal and adult rats. Endocrinol. 134: 2410-2415.

[40] Broedel O, Eravci M, Fuxius S, Smolarz T, Jeitner A, Grau H. Stoltenburg-Didinger G, Plueckhan H, Meinhold H, Baumgartner A (2003) Effects of hyper- and hypothyroidism on thyroid hormone concentrations in regions of the rat brain. Am. J. Physiol. Endocrinol. Metab. 285: E470-E480.

[41] Hashimoto H, Walker CH, Prange AJ, Jr., Mason GA (1991) The effects of thyroid hormones on potassium-stimulated release of ${ }^{3} \mathrm{H}$-GABA by synaptosomes of rat cerebral cortex. Neuropsychopharmacol. 5: 49-54.

[42] Salemi G, Ferraro D, Savattieri G (1990) Triiodothyronine accelerates the synthesis of synapsin $\mathrm{I}$ in developing neurons from fetal rat brain cultured in a synthetic medium. Neurochem. Res. 15: 827-831.

[43] Stahl WL, Harris WE (1986) $\mathrm{Na}^{+}, \mathrm{K}^{+}$-ATPase: structure, function, and interactions with drugs. Adv. Neurol. 44: 681-693.

[44] Vatta M, Pena C, Fernandez B, Rodriguez de Lores AG (1999) A brain $\mathrm{Na}^{+}, \mathrm{K}^{+}$-ATPase inhibitor (endobain E) enhances norepinephrine release in rat hypothalamus. Neurosci. 90: 573-579.

[45] Sarkar PK, Ray AK (1993) Synaptosomal action of thyroid hormones: Changes in $\mathrm{Na}^{+}$$\mathrm{K}^{+}$-ATPase activity in adult rat cerebral cortex. Horm. Metab. Res. 25: 1-3.

[46] Sarkar PK, Ray AK (1998) Specific binding of L-triiodothyronine modulates $\mathrm{Na}^{+}-\mathrm{K}^{+}-$ ATPase activity in adult rat cerebrocortical synaptosomes. NeuroReport 9: 1149-1152.

[47] Mashio Y, Inada M, Tanaka K, Ishii H, Naito K, Nishikawa M, Takahashi K, Imura H (1983). Synaptosomal $\mathrm{T}_{3}$ binding sites in rat brain: their localization on synaptic membrane and regional distribution. Acta Endocrinol. 104: 134-138.

[48] Giguère A, Fortier S, Beaudry C, Gallo-Payet N, Bellabarba D (1996) Effect of thyroid hormones on $G$ proteins in synaptosomes of chick embryo. Endocrinol. 137: 2558-2564.

[49] Davis FB, Cody V, Davis PJ, Borzynski LJ, Blas SD (1983) Stimulation by thyroid hormone analogues of red blood cellCa ${ }^{2+}$ ATPase activity in vitro. Correlations between hormone structure and biological activity in a human cell system. J. Biol. Chem. 258: 12373-12377.

[50] Schmitt CA, McDonough AA (1988) Thyroid hormone regulates alpha and alpha+ isoforms of $\mathrm{Na}, \mathrm{K}-\mathrm{ATPase}$ during development in neonatal rat brain. J. Biol. Chem. 263: 17643-17649.

[51] McDonough AA, Brown TA, Horowitz B, Chiu R, Schlotterbeck J, Bowen J, Schmitt CA (1988) Thyroid hormone coordinately regulates $\mathrm{Na}^{+}-\mathrm{K}^{+}$-ATPase alpha- and beta-subunit mRNA levels in kidney. Am. J. Physiol. 254: C323-C329.

[52] Davis PJ, Davis FB, Cody V (2005) Membrane receptors mediating thyroid hormone action. Trends Endocrinol. Metab. 16: 429-435. 
[53] Friesema EC, Ganguly S, Abdalla A, Manning Fox JE, Halestrap AP, Visser TJ (2003) Identification of monocarboxylate transporter 8 as a specific thyroid hormone transporter. J. Biol. Chem. 278: 40128-40135.

[54] Mason GA, Walker CH, Prange AJ, Jr (1990) Depolarization-dependent ${ }^{45}$ Ca uptake by synaptosomes of rat cerebral cortex is enhanced by L-triiodothyronine. Neuropsychopharmacol. 3: 291-295.

[55] Chakrabarti N, Ray AK (2000) Rise of intrasynaptosomal $\mathrm{Ca}^{2+}$ level and activation of nitric oxide synthase in adult rat cerebral cortex pretreated with 3-5-3'-Ltriiodothyronine. Neuropsychopharmacol. 22: 36-41.

[56] Iqbal Z, Koenig H, Trout JJ (1984) Triiodothyronine (T3) stimulates calcium influx and membrane trasport processes in nerve cells and terminals of hypothyroid mouse cortex. Fed. Proc. 43: 735

[57] Sarkar PK, Ray AK (2003) Calcium mobilization within hypothyroid adult rat brain synaptosomes. Horm. Metab. Res. 35: 562-564.

[58] Divecha N, Irvine RF (1995) Phospholipid signaling. Cell 80: 269-278.

[59] Taussig R, Gilman AG (1995) Mammalian membrane-bound adenylyl cyclases. J. Biol. Chem. 270: 1-4.

[60] Beguin P, Beggah AT, Chibalin AV, Burgener-Kairuz P, Jaisser F, Mathews PM, Rossier BC, Cotecchia S, Geering K (1994) Phosphorylation of the Na,K-ATPase alpha-subunit by protein kinase $\mathrm{A}$ and $\mathrm{C}$ in vitro and in intact cells. Identification of a novel motif for PKC-mediated phosphorylation. J. Biol. Chem. 269: 24437-24445.

[61] Bertorello AM, Aperia A, Walaas SI, Nairn AC, Greengard P (1991) Phosphorylation of the catalytic subunit of $\mathrm{Na}^{+}, \mathrm{K}^{+}$-ATPase inhibits the activity of the enzyme. Proc. Natl. Acad. Sci. U S A 88: 11359-11362.

[62] Cheng XJ, Hoog JO, Nairn AC, Greengard P, Aperia A (1997) Regulation of rat Na(+)$\mathrm{K}(+)$-ATPase activity by PKC is modulated by state of phosphorylation of Ser-943 by PKA. Am. J. Physiol. 273: C1981-C1986.

[63] Cheng XJ, Fisone G, Aizman O, Aizman R, Levenson R, Greengard P, Aperia A (1997) PKA-mediated phosphorylation and inhibition of $\mathrm{Na}(+)-\mathrm{K}(+)$-ATPase in response to beta-adrenergic hormone. Am. J. Physiol. 273(3 Pt 1):C893-C901.

[64] Levitzki A (1988) Signal transduction in hormone-dependent adenylate cyclase. Cell. Biophys. 12: 133-143.

[65] Walz MA, Howlett AC (1987) Thyroid effects on adenosine 3',5'-monophosphate levels and adenylate cyclase in cultured neuroblastoma cells. Endocrinol. 120: 1265-1271.

[66] Lin HY, Shih A, Davis FB, Davis PJ (1999) Thyroid hormone promotes the phosphorylation of STAT3 and potentiates the action of epidermal growth factor in cultured cells. Biochem. J. 338: 427-432.

[67] Scanlan TS, Suchland KL, Hart ME, Chiellini G, Huang Y, Kruzich PJ, Frascarelli S, Crossley DA, Bunzow JR, Ronca-Testoni S, Lin ET, Hatton D, Zucci R, Grandy DK (2004) 3-Iodothyronamine is an endogenous and rapid-acting derivative of thyroid hormone. Nat. Med. 10: 638-642.

[68] Davis PJ, Leonard JL, Davis FB (2008) Mechanisms of nongenomic actions of thyroid hormone. Front. Neuroendocrinol. 29: 211-218. 
[69] Martin JV, Williams DB, Fitzgerald RM, Im HK, VonVoigtlander PF (1996) Thyroid hormonal modulation of the binding and activity of the GABAA receptor complex of brain. Neurosci. 73: 705-713.

[70] Tang HY, Lin HY, Zhang S, Davis FB, Davis PJ (2004) Thyroid hormone causes mitogen-activated protein kinase-dependent phosphorylation of the nuclear estrogen receptor. Endocrinol. 145: 3265-3272.

[71] Lin HY, Zhang S, West BL, Tang HY, Passaretti T, Davis FB, Davis PJ (2003) Identification of the putative MAP kinase docking site in the thyroid hormone receptorbeta1 DNA-binding domain: functional consequences of mutations at the docking site. Biochemistry 42: 7571-7579.

[72] Storey NM, Gentile S, Ullah H, Russo A, Muessel M, Erxleben C. Armstrong DL (2006) Rapid signaling at the plasma membrane by a nuclear receptor for thyroid hormone. Proc. Natl. Acad. Sci. U S A 103: 5197-5201.

[73] Hiroi Y, Kim HH, Ying H, Furuya F, Huang Z, Simoncini T, Noma K, Ueki K, Nguyen NH, Scanlan TS, Moskowitz MA, Cheng SY, Liao, JK (2006) Rapid nongenomic actions of thyroid hormone. Proc. Natl. Acad. Sci. U S A 103: 14104-14109.

[74] Schultz G, Hescheler J (1993) Hormonal modulations of calcium channel activity. Arzneimittel-Forschung Drug Res. 43: 229-232.

[75] Kameyama M, Kameyama A, Kaibara M, Nakayama T, Irisawa H (1990) Intracellular mechanisms involved in "run-down" of calcium channels. Adv. Exp. Med. Biol. 255: 111-118.

[76] Dolphin AC (1995) Voltage-dependent calcium channels and their modulation by neurotransmitters and G proteins. Experimental Physiol. 80: 1-36.

[77] Lingham RB, Sen AK (1982) Regulation of rat brain (Na++K+)-ATPase activity by cyclic AMP. Biochim. Biophys. Acta 688: 475-485.

[78] Patwardhan P, Miller WT (2007) Processive phosphorylation: mechanism and biological importance. Cell. Signal. 19: 2218-2226.

[79] Manning G, Plowman GD, Hunter T, Sudarsanam S (2002) Evolution of protein kinase signaling from yeast to man. Trends Biochem. Sci. 27: 514-520.

[80] Choi EJ, Xia Z, Villacres EC, Storm DR (1993) The regulatory diversity of the mammalian adenylyl cyclases. Curr. Opin. Cell. Biol. 5: 269-273.

[81] Laurent-Demir C, Decorte L, Jaffard R, Mons N (2000) Differential regulation of Ca(2+)calmodulin stimulated and $\mathrm{Ca}(2+)$ insensitive adenylyl cyclase messenger RNA in intact and denervated mouse hippocampus. Neurosci. 96: 267-274.

[82] Tang WJ, Iniguez-Lluhi JA, Mumby S, Gilman AG (1992) Regulation of mammalian adenylyl cyclases by G-protein alpha and beta gamma subunits. Cold Spring Harb. Symp. Quant. Biol. 57: 135-144.

[83] Gerges NZ, Alkadhi KA (2004) Hypothyroidism impairs late LTP in CA1 region but not in dentate gyrus of the intact rat hippocampus: MAPK involvement. Hippocampus 14: 40-45.

[84] Lei J, Mariash CN, Ingbar DH (2004) 3,3',5-Triiodo-L-thyronine up-regulation of Na,KATPase activity and cell surface expression in alveolar epithelial cells is Src kinase- and phosphoinositide 3-kinase-dependent. J. Biol. Chem. 279: 47589-47600. 
[85] Sarkar S, Biswas SC, Chatterjee O, Sarkar PK (1999) Protein kinase A Linked phosphorylation mediates triiodothyronine induced actin gene expression in developing brain. Mol. Brain Res. 67: 158-164.

[86] Wang X, Rostas JAP (1996) Effect of hypothyroidism on the subcellular distribution of $\mathrm{Ca}^{2+} /$ calmodulin-stimulated protein kinase II in chicken brain during posthatch development. J. Neurochem. 66: 1625-1632.

[87] Sarkar PK, Morris JJ, Martin JV (2011) Non-genomic effect of L-triiodothyronine on calmodulin-dependent synaptosomal protein phosphorylation in adult rat cerebral cortex. Indian J. Exp. Biol. 49: 169-176. 